\title{
Caledonian and Knoydartian overprinting of a Grenvillian inlier and the enclosing Morar Group rocks: structural evolution of the Precambrian Proto-Moine Nappe, Glenelg, NW Scotland
}

\author{
M. Krabbendam ${ }^{\text {1, * }}$, J. G. Ramsay ${ }^{2}$, A. G. Leslie ${ }^{1}$, P. W. G. Tanner ${ }^{3}$, D. Dietrich ${ }^{2}$ \& K. M. \\ Goodenough ${ }^{1}$ \\ ${ }^{1}$ British Geological Survey, Lyell Centre, Research Avenue South, Edinburgh EH14 4AP, UK \\ ${ }^{2}$ Cratoule, Issirac, France \\ ${ }^{3}$ School of Geographical and Earth Sciences, University of Glasgow, Glasgow G2 8QQ, UK \\ * Corresponding author: email: $\underline{\text { mkrab@bgs.ac.uk }}$
}

Keywords: Poly-orogenic; nappe; eclogite; refolding

\begin{abstract}
The Grenville and Caledonian orogens, fundamental to building Laurentia and Baltica, intersect in northern Scotland. The Precambrian Glenelg Inlier, within the Scottish Caledonides preserves a record of Grenvillian, Knoydartian and Caledonian orogenesis. Based on new mapping and re-interpretation of previous mapping, we present a structural model for the evolution of the Glenelg Inlier. The inlier can be divided into Western Glenelg gneiss comprising orthogneiss with no record of Grenville-age metamorphism, and Eastern Glenelg gneiss with ortho- and para-gneiss, affected by Grenvillian eclogite-facies metamorphism. The basement gneisses and their original cover of psammitic, Neoproterozoic Morar Group (Moine) rocks were deformed by three generations of major ductile folds (F1-F3). In medium-strain areas F2 and F3 folds are broadly coaxial and both face to the west; in higher strain areas F2 and F3 folds are oblique to each other. . By restoring post-F1 folds and late faults, the Glenelg gneiss inliers are seen to form the core of a major recumbent SSE-facing F1 isoclinal fold nappe - the Proto-Moine Nappe. The upper limb of this nappe is a thick, right-way-up sequence of moderately strained Morar Group rocks whereas the lower, inverted limb comprises intensely deformed, migmatitic Morar Group rocks. Within the constraints of published geochronology, the Proto-Moine Nappe is likely Pre-Caledonian and may have originated during the early Neoproterozoic Knoydartian Orogeny.
\end{abstract}




\section{Introduction}

The Grenville-Sveconorwegian and Caledonian-Appalachian orogens represent pivotal tectonic events in the evolution of the continental masses of Laurentia and Baltica (Fig. 1). The c. 1200-960 Ma Grenville-Sveconorwegian Orogen stretches from Mexico to Southern Sweden, and is one of the largest collisional belts on Earth (e.g., Rivers 1997, 2008; Tollo et al. 2004; Tohver et al. 2004). The ArchaeanPalaeoproterozoic Glenelg Inlier in Scotland and the Annagh Gneiss Complex in Ireland provide small but crucial links between the North American and Scandinavian parts of the orogen (Sanders et al. 1984; Daly 1996; Brewer et al. 2003; Storey et al. 2010). The Glenelg Inlier of Scotland, however, occurs within the much later 470-400 Ma Caledonian Orogen (e.g., McKerrow et al. 1991; Woodcock \& Strachan 2012; Chew \& Strachan 2014; Dewey et al. 2015) and has thus been strongly reworked.

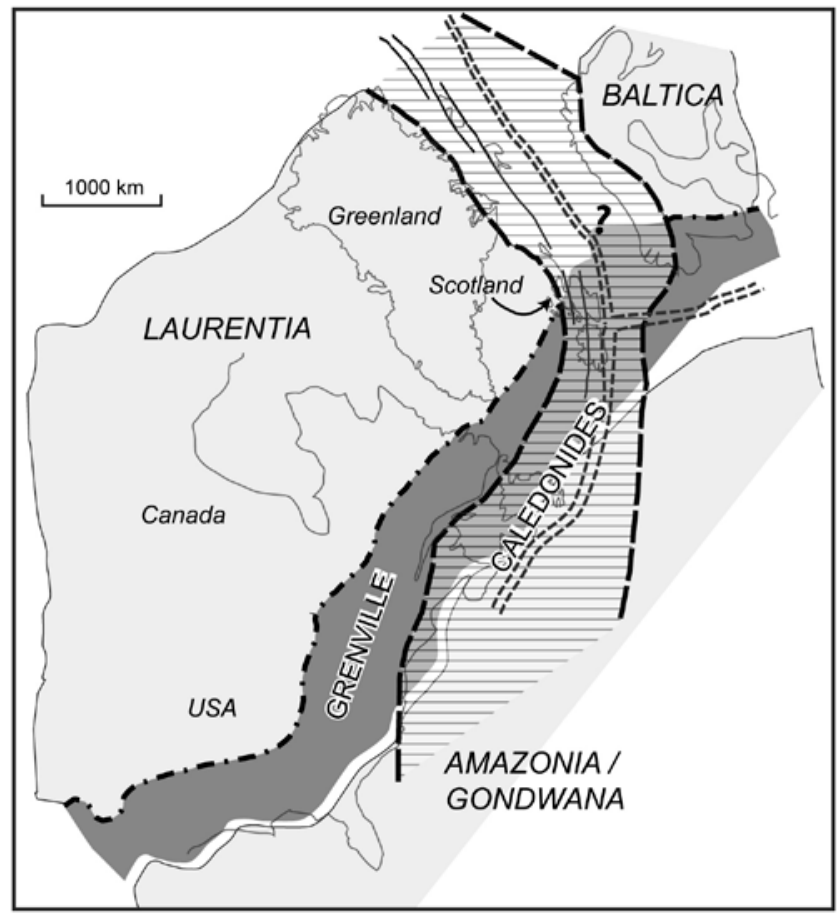

Fig. 1. Schematic reconstruction of the Grenville-Sveconorwegian Orogen (1200-960 Ma) with the trace of the Caledonian Orogen (470-400 Ma) superimposed (striped). Trace of the Iapetus Ocean indicated by double dashed line. Note that different parts of Amazonia / Gondwana collided with Laurentia during the Grenville and Caledonian orogens respectively and that the relative position of Baltica and Laurentia is that during the Palaeozoic. Modified after Tohver et al. (2004); Cawood et al. (2007); Bingen et al. (2008).

The Glenelg Inlier in the Northern Highlands of Scotland (Fig. 2) preserves Grenvillian-age eclogite-facies assemblages, but is surrounded by metasedimentary rocks of the early Neoproterozoic Morar Group (Fig. 2), the lowest tectono-stratigraphic unit of the Moine Supergroup (Holdsworth et al. 1994). Detrital zircon dating has shown that Morar Group deposition was later than, or possibly coeval with, the Grenville-age high-pressure metamorphism in the Glenelg Inlier (Brewer et al. 2003; Friend et 
al. 2003; Kirkland et al. 2008; Cawood et al. 2015). The Morar Group, together with the Sleat and Torridon groups in the Caledonian foreland, is now interpreted as a remnant of the foreland basin to the Grenville Orogen (Rainbird et al. 2001; Krabbendam et al. 2008; Bonsor et al. 2010, 2012;

Krabbendam \& Rainbird 2012; Krabbendam et al. 2017).
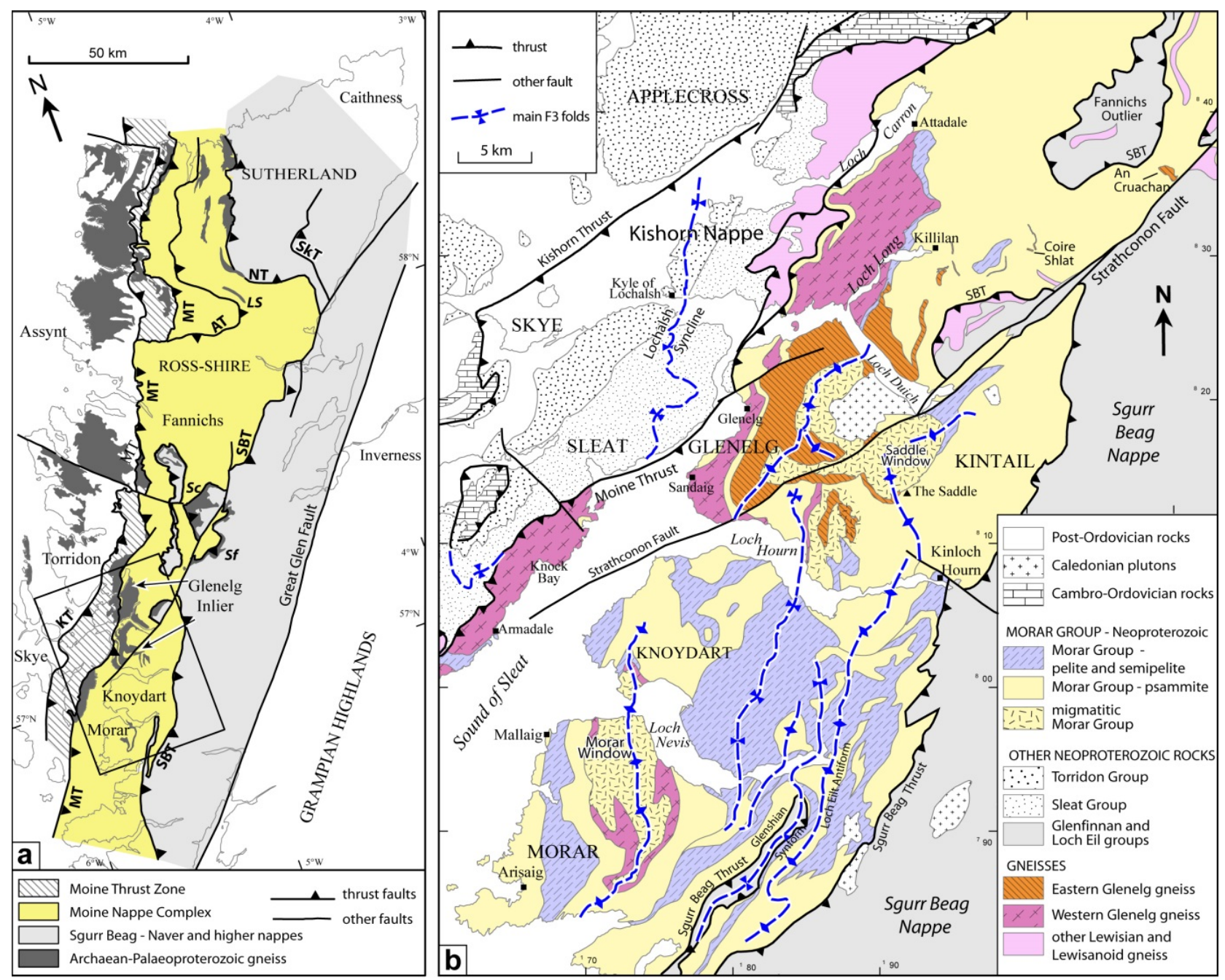

Fig. 2. (a) Main thrust sheets in Northern Highlands, with basement gneiss outcrops. Thrusts: AT = Achness Thrust; KT = Kishorn Thrust; MT $=$ Moine Thrust; NT $=$ Naver Thrust; $\mathrm{SBT}=$ Sgurr Beag Thrust; SkT $=$ Skinsdale Thrust. Gneiss Inliers: LS = Loch Shin Inlier; Sc = Scardroy Inlier; Sf = Strathfarrar Inlier. After British Geological Survey (2007); Strachan et al. (2010). Box is outline of Figure 2b.

(b) Geological map of the Glenelg Inlier and surrounding area, showing distribution of Western and Eastern Glenelg inliers. After Geological Survey of Scotland (1909), British Geological Survey (1971, 1984), Powell (1974); Mendum (2009b) and mapping by the authors.

The post-Grenvillian evolution of the Glenelg Inlier and surrounding Morar Group rocks is complicated and involved several episodes of tectonic reworking, including one or more phases of Knoydartian (Neoproterozoic, c. 825-720 Ma) activity, as well as Grampian (Ordovician) and Scandian (Silurian) deformation during Caledonian orogenesis (e.g., Van Breemen et al. 1974; Rogers et al. 1998; 
Vance et al. 1998; Kinny et al. 1999; Cutts et al. 2009; 2010; Bird et al. 2013; Cawood et al. 2015).

The Glenelg Inlier has been well studied in terms of its structure, petrology, and geochronology (Alderman 1936; Ramsay 1958, 1963; Tanner 1965, Sanders et al. 1984; Sanders 1988, 1989; Rawson et al. 2001; Storey et al. 2004; 2005; 2008a, b; Barber 2011). A number of structural studies have been carried out in the surrounding areas (Clifford 1957; Ramsay \& Spring 1962; Tanner 1965; Poole \& Spring 1974; Powell 1966; 1974; Simony 1973). This region has served as a natural laboratory for structural geology; in particular for the geometrical analysis of large- and small scale fold interference patterns and folded lineations (Ramsay 1958, 1960, 1962, 1967). Nevertheless, it remains uncertain which structures (folds, fabrics, thrusts) can be attributed to which orogenic event (e.g., Knoydartian, Grampian, Scandian) and where the limits or 'orogenic fronts' of these different orogenies were situated (e.g., Bird et al. 2013; Cawood et al. 2015; Dewey et al. 2015). Consequently, the structural setting and tectonic evolution of the Glenelg Inlier within the larger framework of the Scottish Caledonides has remained elusive (cf. Temperley \& Windley 1997; Sanders et al. 1997; Storey 2008a; Storey et al. 2010; Barber 2011).

In this paper, we present an analysis of the geometry and structural evolution of the Glenelg Inlier and surrounding Morar Group rocks. In addition to referenced material, the datasets we use are: i) detailed mapping by JGR and DD from the southern Glenelg Inlier and immediate surrounding Morar Group; ii) detailed mapping data from the Loch Hourn areas from PWGT (described in detail in Tanner 1965) and iii) reconnaissance and targeted detailed mapping in Knoydart and the northern Glenelg Inlier by MK, AGL and KMG.

\section{Geological Setting}

\section{The Moine Nappe and its setting}

The Scottish Caledonides are dominated by two thrust systems: the lower Moine Thrust Zone in the west and the higher Sgurr Beag / Naver Thrust system farther east (Fig. 2a; e.g. Tanner 1971; Strachan et al. 2010). The undeformed Foreland of the Caledonides to the NW comprises ArchaeanPalaeoproterozoic Lewisian gneiss, overlain by early Neoproterozoic Torridon Group sandstone, in turn unconformably overlain by a Cambro-Ordovician shelf sequence. The Moine Thrust Zone is a fold-andthrust belt that imbricates this distinctive succession, and is capped by the brittle-ductile Moine thrust (e.g., Peach et al. 1907; Elliott \& Johnson 1980; Coward 1983; Krabbendam \& Leslie 2010; Butler 2010; Thigpen et al. 2010).

On the Isle of Skye west of Glenelg, the Moine Thrust Zone is dominated by the large-scale recumbent Lochalsh Syncline within the Kishorn Nappe (Bailey 1955; Coward \& Potts 1985), which contains a thick sequence of Neoproterozoic siliciclastic sedimentary rocks of the Sleat and lower 
Torridon groups (Stewart 2002; Kinnaird et al. 2007; Krabbendam et al. 2017). The Moine Nappe, above the Moine Thrust, comprises a large (>50 x $200 \mathrm{~km}$ ) outcrop of metasedimentary Morar Group rocks, with basement inliers including the Glenelg Inlier, mostly deformed under amphibolite-facies conditions (e.g., Barr et al. 1986; Strachan et al. 2010; Thigpen et al. 2013). In Sutherland, the northern Moine Nappe (sensu lato) comprises several thin $(<1-2 \mathrm{~km})$ ductile thrust slices, each containing strongly sheared Morar Group rocks and basement gneisses (e.g., Barr et al. 1986; Strachan and Holdsworth 1988; Holdsworth 1989; Holdsworth et al. 2007). In contrast, in Ross-shire (Fig. 2a), the central Moine Nappe is a single entity with large-scale west-vergent folds but no structural breaks (Leslie et al. 2010; Krabbendam et al. 2011). In this area, a clear Morar Group succession, many kilometres thick, has been documented, the lower part of which has been correlated with the Torridon Group west of the Moine Thrust (Krabbendam et al. 2008; Bonsor et al. 2010, 2012). A similarly thick sequence of Morar Group rocks occurs in Morar and Knoydart and, despite high-grade metamorphic overprint, the gross stratigraphies of Ross-shire, Knoydart and Morar can be correlated (Fig. 3) (Johnstone et al. 1969; Holdsworth et al. 1994; Krabbendam et al. 2014). The Glenelg Inlier occurs within the Moine Nappe, between these two areas of well-established Morar Group stratigraphy (Ramsay \& Spring 1962).

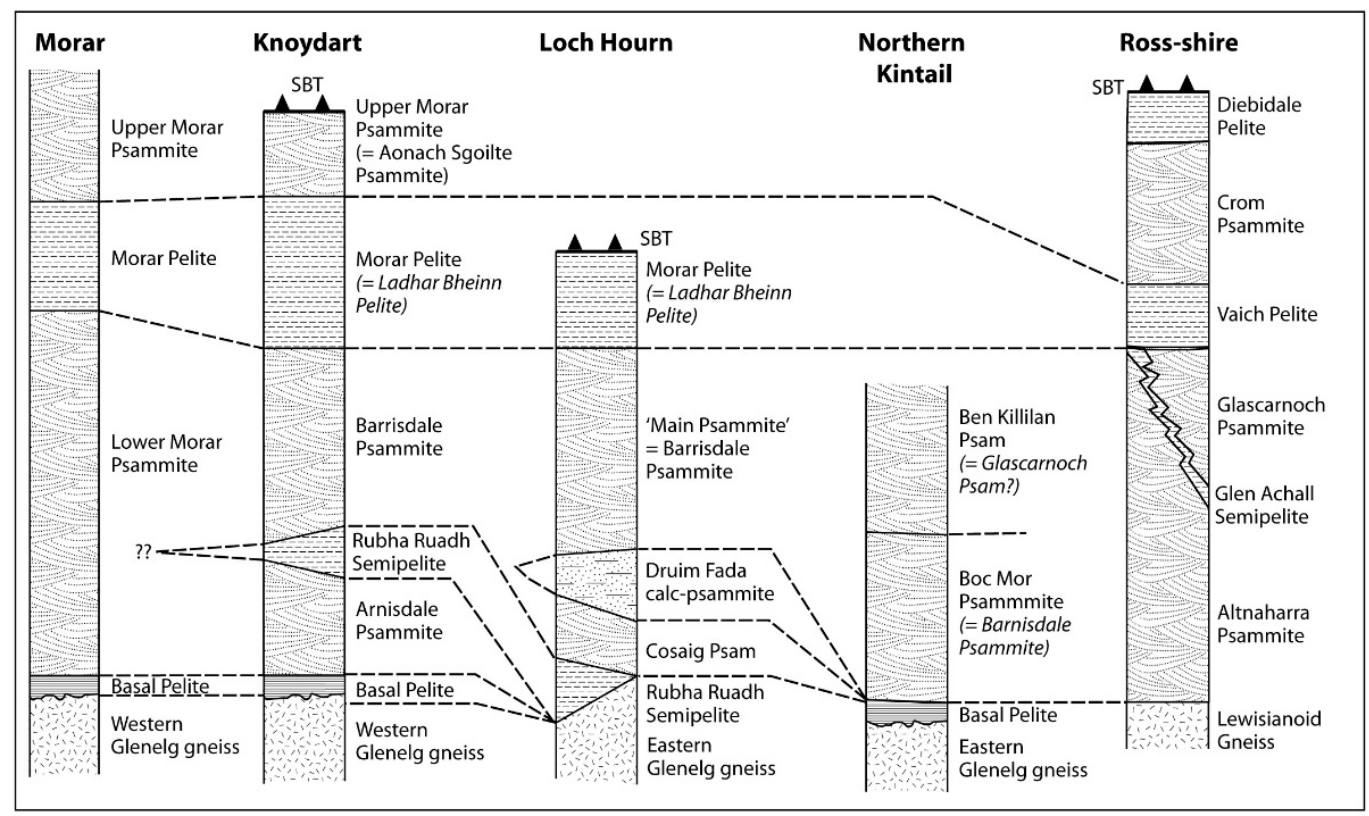

Fig. 3. Stratigraphy of the Morar Group in different sub-areas, from the SW (Morar) to the NE (Ross-shire). Morar: Johnstone et al. (1969); Knoydart: Ramsay \& Spring (1962); Loch Hourn: Tanner (1965); Northern Kintail: May et al. (1993); Ross-shire: Bonsor et al. (2012). SBT = Sgurr Beag Thrust. 


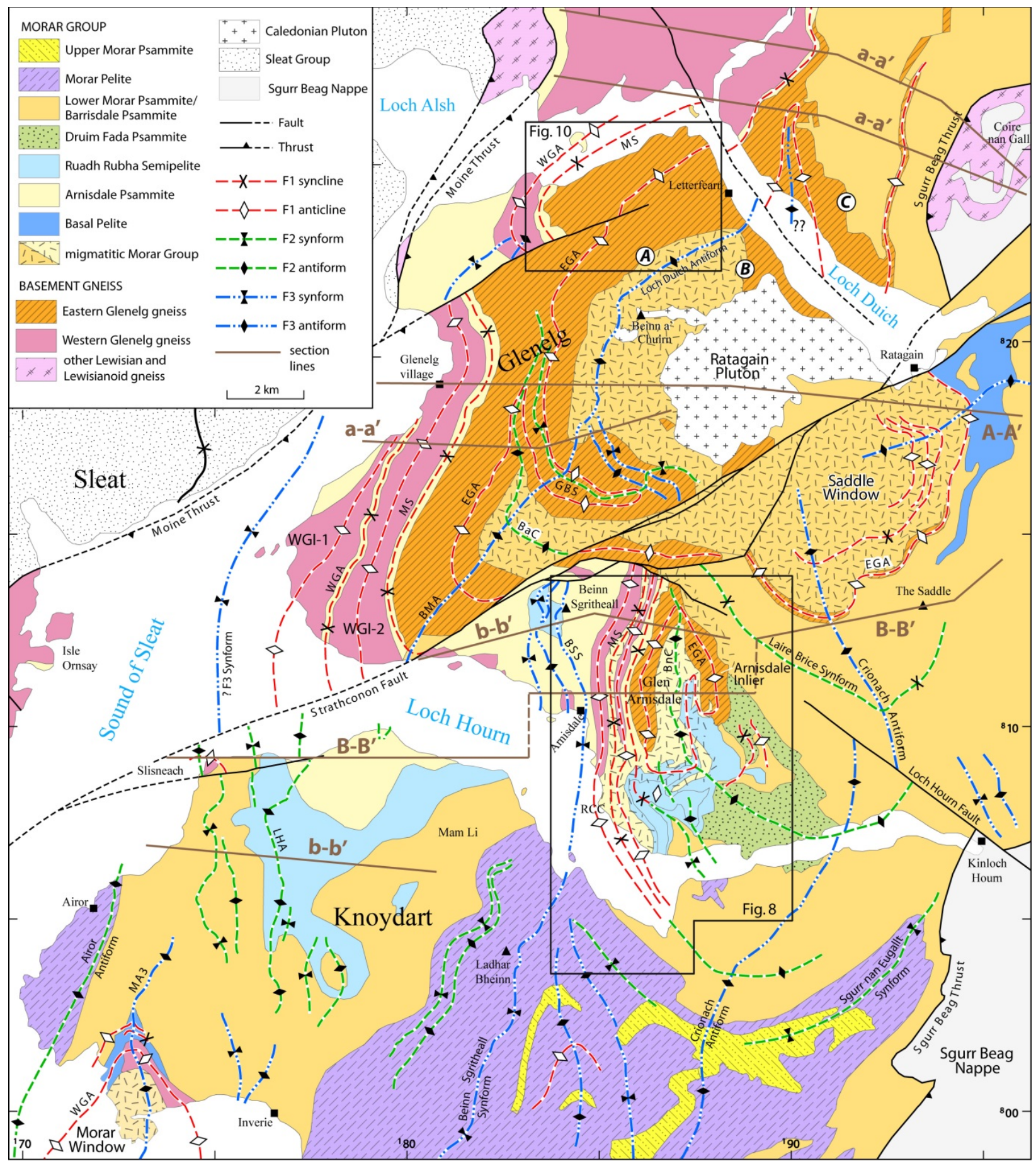

Fig. 4. Geological map of the Glenelg Inlier and surrounding area, with Morar Group units subdivided and major fold traces shown. After British Geological Survey (1971; 1984), Ramsay \& Spring (1962); Tanner (1965); Simony (1973) and mapping by the authors. Abbreviations for fold axial traces: $\mathrm{BaC}=$ Beinn a' Chapuill Antiform (F2); BnC = Beinn nan Caorach Antiform (F2); BSS = Beinn Sgritheal Synform (F3); BMA = Beinn Mhialairigh Antiform (F3); GBS = Gleann Beag Synform (F2); MA3 = Morar Antiform (F3); MS = Median Syncline (F1); LHA = Loch Hourn Antiform (F2); WGA = Western Glenelg Anticline (F1); EGA = Eastern Glenelg Anticline (F1). Inliers: WGI-1; WGI-2: Western Glenelg Inlier 1 and 2; RCC = Rubha Camas na Cailinn. Boxes show outlines of Figures 8 and 10. Main section lines (A-A' and B-B') and supporting section lines (a-a' and b-b') of Figure 9 are indicated. Points $\boldsymbol{A}, \boldsymbol{B}$ and $\boldsymbol{C}$ described in text. 
The Moine Nappe Complex is structurally overlain by the ductile, amphibolite-facies Sgurr Beag Thrust (Fig. 2) (Tanner 1971, 1976; Powell et al. 1981; Roberts et al. 1987). The overlying Sgurr Beag Nappe comprises the pelitic Glenfinnan and the psammitic Loch Eil groups, and a number of slices of basement gneiss, typically below the Glenfinnan group at or near the Sgurr Beag Thrust (e.g., Roberts et al. 1987; Strachan et al. 1988). From the Fannichs Inlier southward, the Sgurr Beag Thrust and Nappe are refolded by folds with axial planes that steepen towards the east (e.g., Roberts \& Harris 1983; Roberts et al. 1987).

\section{The Glenelg Inlier}

The Glenelg Inlier (Figs. 2, 4), also termed the Glenelg-Attadale Inlier (e.g., Storey 2008a; Barber 2011), contains two lithologically very different assemblages, termed here 'Western Glenelg gneiss' and ‘Eastern Glenelg gneiss’; previous names include ‘Western Lewisian / Eastern Lewisian’ or the 'Western Unit / Eastern Unit of the Glenelg-Attadale Inlier’ (Ramsay 1958; Sutton \& Watson 1958; Storey et al. 2004; Storey 2008a). As these two different gneiss assemblages occur in a number of separate inliers (sensu stricto), we first summarise their general lithological characteristics before assigning rocks within the different inliers to a particular assemblage. Comprehensive overviews of the lithology and petrology of the Glenelg Inlier were provided by Storey (2008a, b) and Mendum (2009a), and only a summary is given here.

\section{Western Glenelg gneiss}

The Western Glenelg gneiss assemblage consists solely of meta-igneous rocks. These include hornblende-bearing quartzo-feldspathic grey gneiss with abundant inclusions of meta-mafic rocks, mainly of amphibolite, but also including hornblendite, pyroxene-bearing mafic high-pressure granulite and very rare eclogite (Barber \& May 1976; Sanders 1988; Storey et al. 2005; Storey 2008a, b). Strain is highly variable: agmatitic textures are locally preserved, with intimate intermingling of mafic and felsic meta-igneous material, suggesting very low strain (Fig. 5a). Elsewhere the gneisses show an intensely developed 'tramline' banding, showing extremely high finite strains (Fig. 6c). Locally, amphibolite sheets cross-cut an earlier gneissic layering and likely represent metamorphosed dykes, similar to the 'Scourie Dykes’ of the Caledonian Foreland (Ramsay 1958). Western Glenelg gneiss is similar to gneisses exposed below the Moine Thrust near Lochcarron (Barber \& May 1976) and a correlation with the Lewisian Gneiss Complex seems valid. Both the protolith of the felsic gneiss as well as an early granulite-facies metamorphism are of Archaean age (Friend et al. 2008; Storey et al. 2010). High-pressure granulite-to-eclogite facies metamorphism occurred at c. 1.75 Ga (Storey et al. 2010), but there is no evidence for Grenvillian metamorphism. 

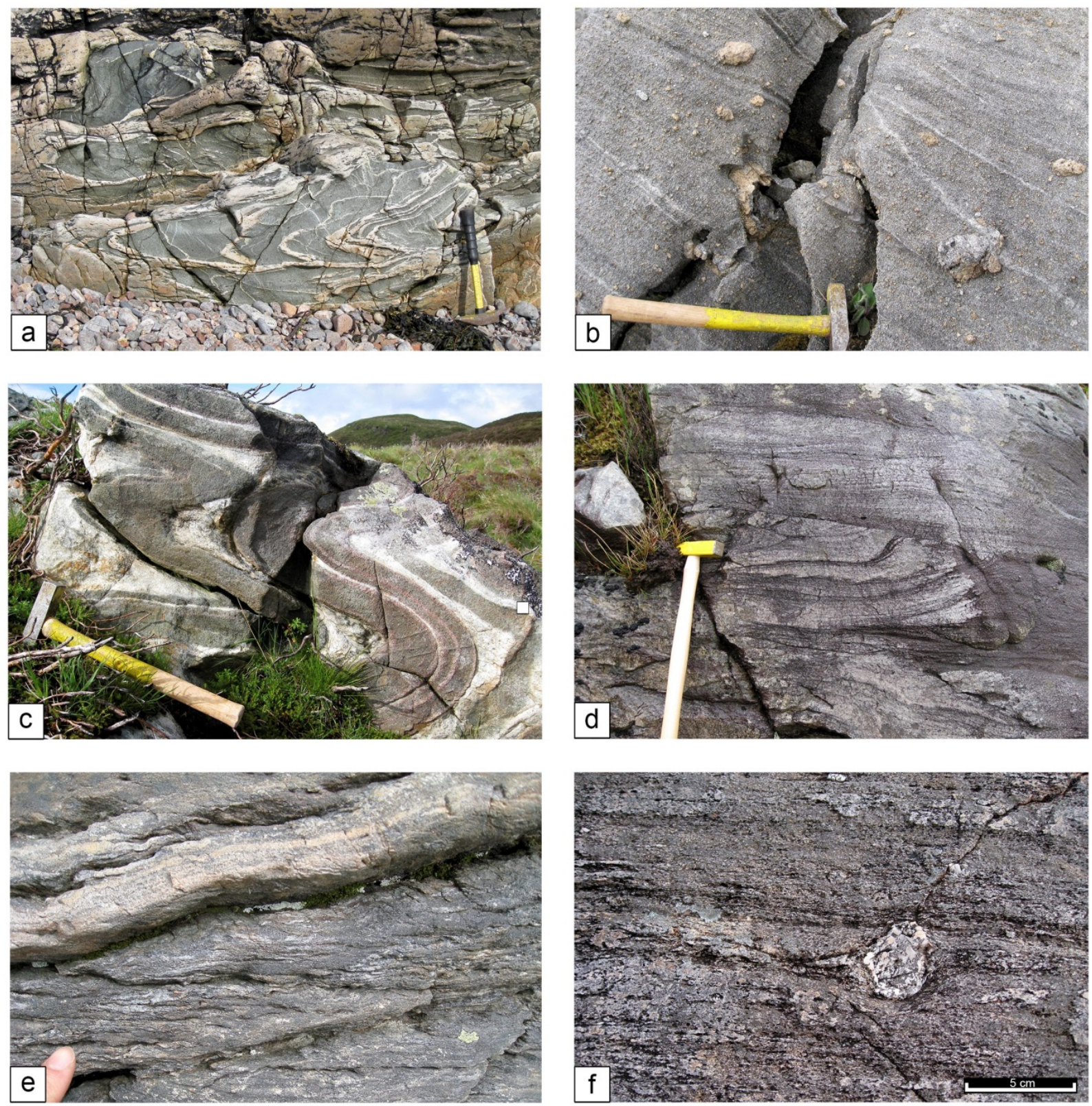

Fig. 5. Field photographs of lithologies of Glenelg gneiss and Morar Group. (a) Agmatitic texture in Western Glenelg gneiss, showing relic magma mixing of original felsic and mafic rocks. Glenelg village. Hammer $40 \mathrm{~cm}$ long. BGS Photo P707935. (b) Marble with calc-silicate nodules; Eastern Glenelg gneiss. North of Glen Beag. BGS Photo P779470. (c) Layered mafic and felsic eclogite, folded; Eastern Glenelg gneiss. BGS Photo P779489. (d) Coarse psammite with trough cross-bedding, truncated by planar bedded psammite, right-way-up. Barrisdale Psammite, Morar Group, central Knoydart (Mam Li). BGS Photo P779591. (e) Unconformity of thinly bedded psammite and semipelite (Morar Group) above intermediate gneiss (Western Glenelg gneiss), preserving angular relationship between bedding and gneissose fabric. Slisneach, NW Knoydart. BGS Photo P779573. (f) Coarse psammite with quartzo-feldspathic segregations and sigma-clast of deformed pegmatite. Migmatitic Morar Group, just east of Eastern Glenelg gneiss; NW of Beinn a' Chuirn. BGS Photo P779499. 


\section{Eastern Glenelg gneiss}

The Eastern Glenelg gneiss assemblage contains abundant paragneiss in addition to orthogneiss. Rocks of sedimentary origin include kyanite-garnet-bearing pelitic gneiss, graphitic pelite, forsterite marble with large conspicuous nodules of diopside, tremolite and forsterite (Fig. 5b), and a variety of gneissose semipelitic to psammitic rocks (Peach et al. 1910; Alderman 1936; Rawson et al. 2001; Sanders 1988; Storey et al. 2005; Storey 2008a, and our observations). Eclogite boudins or layers (Fig. 5c), commonly retrogressed to symplectitic eclogite or amphibolite, are abundant in both paragneisses and orthogneisses. Many eclogite bodies probably originated as mafic intrusions, but some thin, laterally extensive eclogite layers in paragneiss have gradational boundaries, and may have a volcanic or volcaniclastic origin. Felsic eclogite, comprising kyanite, quartz and K-feldspar occurs locally (Sanders 1988; Storey et al. 2005; Storey 2008b). Rare ultramafic rocks include garnet-bearing websterite (Rawson et al. 2001).

Peak-metamorphic conditions have been estimated at $17-23$ kbar at $730-780{ }^{\circ} \mathrm{C}$ (Sanders 1989 ; Rawson et al. 2001; Storey et al. 2005), although Sajeev et al. (2010) suggested higher estimates. The eclogite-facies metamorphism has been dated at $1082 \pm 82$ Ma (Sm-Nd on garnet; Sanders et al. 1984), and subsequent amphibolite-facies retrogression, involving near isothermal decompression (Storey et al. 2005), has been dated at $995 \pm 8 \mathrm{Ma}$ (U-Pb on zircon and titanite; Brewer et al. 2003). These dates provide unequivocal evidence for Grenvillian high-pressure metamorphism, followed by lateGrenvillian exhumation, in the Eastern Glenelg gneiss.

\section{The Morar Group and contacts with the basement}

The Morar Group is dominated by a broad tripartite grouping (Fig. 3) of Lower Morar Psammite Formation - Morar Pelite Formation - Upper Morar Psammite Formation - or their lateral equivalents (e.g., Richey \& Kennedy 1939; Johnstone et al. 1969; Holdsworth et al. 1994, Bonsor et al. 2012). In Knoydart, Ramsay and Spring (1962) further subdivided the Lower Morar Psammite Formation into four units, from base to top: the Basal Pelite, Arnisdale Psammite, Rubha Ruadh Semipelite and Barrisdale Psammite (see also Krabbendam et al. 2014). Deposition of the Morar Group occurred after c. $1000 \mathrm{Ma}$, as indicated by the youngest recorded zircons (Friend et al. 2003; Kirkland et al. 2008; Cawood et al. 2015). Although much of the Morar Group is strongly deformed, sedimentary structures are locally well preserved in low strain zones (Fig. 5d), and sedimentological analysis points to deposition in both braided-river fluviatile and shallow marine environments (Glendinning 1988; Bonsor \& Prave, 2008; Krabbendam et al. 2008; Bonsor et al. 2010; 2012). The Morar Group has an original unconformable relationship against Western Glenelg gneiss, with good evidence for a metaconglomerate at the contact at Attadale [NG 913 377] and SW of Glenelg village [NG 793 174] 
(Figs. 2 and 4 for locations), as well as angular relationships between gneissosity and bedding SSW of Glenelg village (Peach et al. 1910; Ramsay 1958; Barber 2009) and near Slisneach in NW Knoydart

(Fig. 5e; Krabbendam et al. 2014). In contrast, no unequivocal evidence for an unconformable contact between the Morar Group and the Eastern Glenelg gneiss has been found.

Migmatitic Morar Group rocks are psammitic, semipelitic and pelitic rocks that are strongly recrystallized, showing coarse-grained gneissose and commonly migmatitic textures (Fig. 5f; see also Richey \& Kennedy 1939; Kennedy 1955; Lambert 1958; Lambert \& Poole 1964; Simony 1973; May et al. 1993). These rocks were termed 'Sub-Moine’ by Richey \& Kennedy (1939), but were subsequently recognised as belonging to the Morar Group (e.g., Kennedy 1955; Tanner 1965). Quartz and quartzfeldspar segregations with stromatic or augen textures occur locally; pegmatite is also common. Sedimentary structures and younging evidence have generally been obliterated by pervasive recrystallisation and deformation and localised partial melting. In the remainder of this paper, these rocks are referred to as “migmatitic Morar Group”.

\section{Faulting and intrusion}

The eastern part of the Glenelg Inlier was intruded by the late-Caledonian monzonite - monzodiorite Ratagain Pluton, dated at $425 \pm 3$ Ma (Rogers \& Dunning 1991). Intrusion of the pluton is thought to be associated with movement along the Strathconon Fault (Hutton \& McErlean 1991), one of a family of Silurian-Devonian NE-SW sinistral strike- slip faults found throughout the Scottish Highlands (Watson 1984). The fault cuts and displaces the Ratagain Pluton (Fig. 4) and associated dykes (Peach et al. 1910; Hutton \& McErlean 1991) with an apparent sinistral displacement.

\section{Deformation phases}

The analysis, definition and correlation of different deformation phases in polydeformed terranes is fraught with difficulty and can lead to confusion (e.g., Forster \& Lister 2008). Throughout the Moine, different authors have used different deformation-phase schemes (overviews in Powell 1974, and Storey 2008a). The deformation phases referred to in this paper are characterized as follows.

- D1 is represented by isoclinal folds (Fig. 6a, b), that are refolded by D2 folds and/or overprinted by D2 fabrics. These folds are commonly only recognisable by careful mapping and recognition of repetition within the sequence, and interfolding of basement gneiss and metasediment. Because of strong subsequent deformation and recrystallisation, linear features related to F1 folds are rare. Where abundant (e.g., in Glen Arnisdale, Fig. 4), they are characterized by quartz rodding that is lacking in feldspar (Ramsay 1963). Quartz vein development was particularly strong prior to F1, so that many F1 folds deform quartz veins but not quartzo-feldspathic segregations, which only developed after F1 
folding (Tanner 1965, p $95 \mathrm{ff}$.). This suggests that the metamorphic grade of D1 did not reach that of the peak-metamorphic conditions during D2.
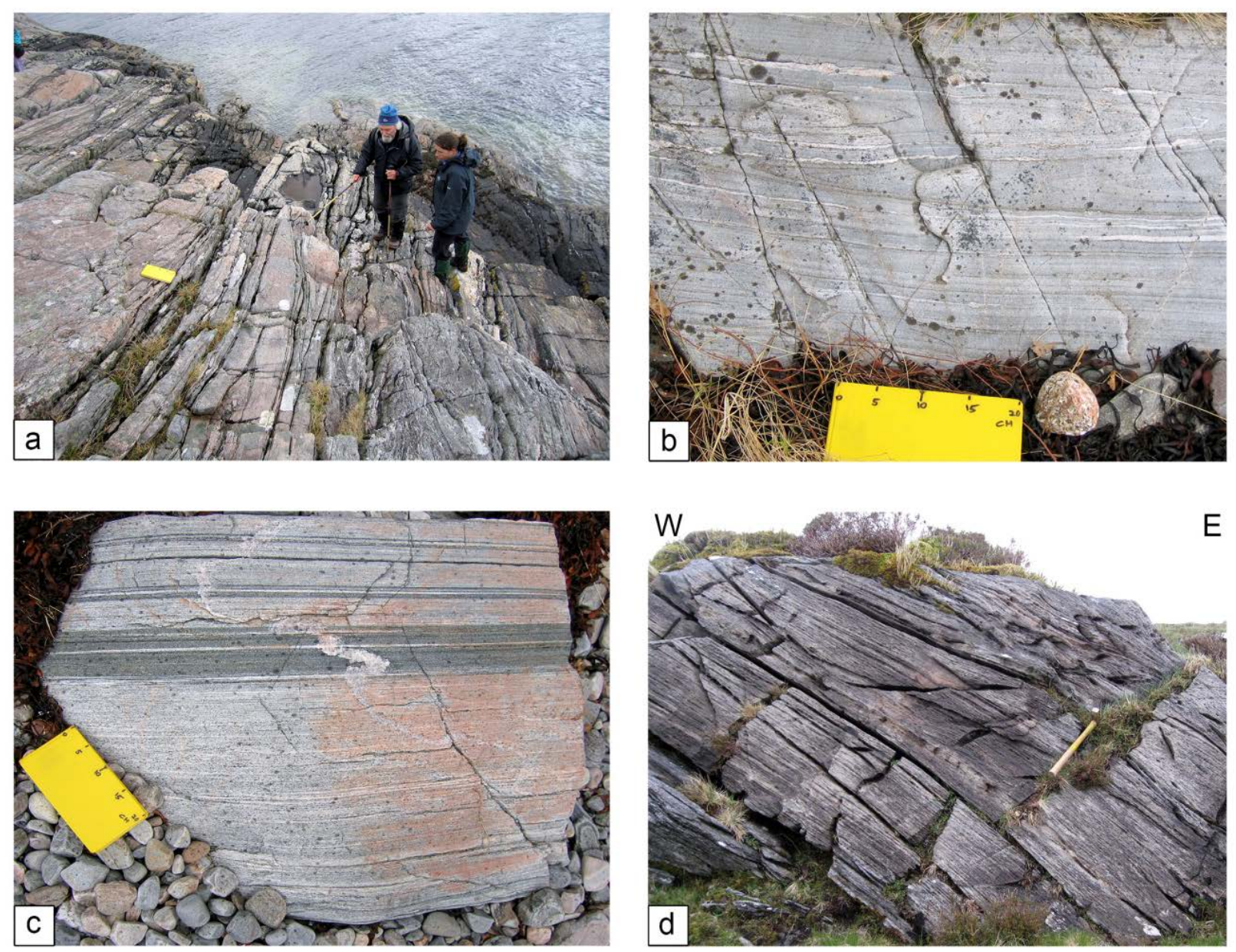

Fig. 6. Field photographs of early structures: F1 folds and shear zones.

(a) Isoclinal F1 folding of Morar group psammite and Western Glenelg gneiss. Viewed downward to south. Rubha Camas na Cailinn. BGS Photo P707471. (b) Isoclinal F1 folds within Morar group psammite, looking west; between Coran village and Rubha Camas na Cailinn. BGS Photo P707458. (c) Very finely banded, ultramylonitic gneiss, cut by thin pegmatite, western margin of WGI-1 inlier, Western Glenelg gneiss, south of Arnisdale village. BGS Photo P707451. (d) Strongly sheared, talc-amphibolite mylonite along eastern boundary of Eastern Glenelg gneiss, Inverinate Shear Zone, west of Beinn a’ Chuirn. Hammer $40 \mathrm{~cm}$ long; view to NNE. BGS Photo P779508.

- D2 structures are characterized by amphibolite-facies fabrics (S2 and L2) that are penetrative in most lithologies. In psammitic rocks, S2 is characterized by a quartz-flattening fabric and alignment of dispersed flakes of biotite, whereas in pelitic rocks the S2 fabric is normally a well-developed micadominated schistosity. In calc-silicate rocks most metamorphic minerals (garnet, zoisite, biotite, amphiboles) grew or recrystallized during F2, although some hornblende growth outlasted F2 deformation (Tanner 1976). Within Eastern Glenelg gneiss, earlier-formed kyanite, staurolite and garnet 
remained stable, whereas eclogite minerals were further retrograded to garnet amphibolite (Alderman 1936; Storey 2008a). Within Western Glenelg gneiss, garnet remained stable. In the Basal Pelite and at some locations in the Western Glenelg Inlier (Sandaig, Attadale, and Knock Bay on Skye, see Fig. 2 for locations), hornblende occurs either as prismatic crystals defining the local D2 mineral lineation or as garbenschiefer in which randomly orientated porphyroblasts lie in the S2 fabric. Low in the structural pile, D2-related metamorphism was locally accompanied by migmatization and the formation of quartzfeldspar-mica segregations (Tanner 1965, Plate 23). However, some quartz-feldspar-mica segregations and pegmatite intrusions cross-cut F2 folds, but are deformed by F3 folds (Tanner 1965, Plate 24). In summary, peak metamorphism was broadly coeval with D2, but some mineral growth and partial melting outlasted D2 deformation (Ramsay 1963; Tanner 1965; 1976).
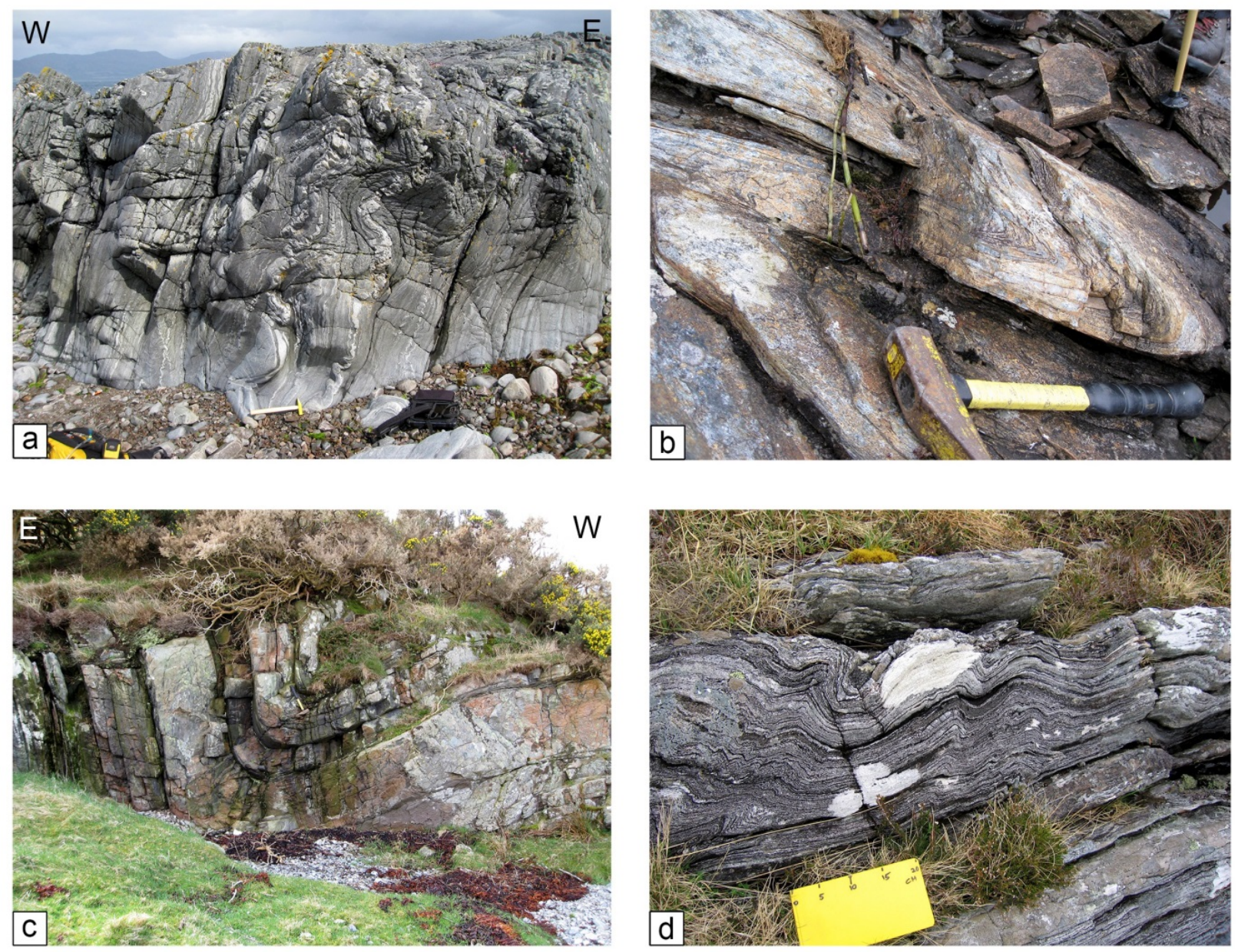

Fig. 7. Field photographs of D2 and D3 structures.

(a) F2 folds, modest strain. Open-close, recumbent folds; in west-facing hinge zone of Airor Antiform; basal part of Morar Pelite Formation. View to north; near Airor, west Knoydart. BGS Photo P779625. Height of outcrop c. 3 m. (b) F2 folds, high strain. Tight to isoclinal F2 folds in Western Glenelg gneiss, $2.5 \mathrm{~km} \mathrm{SSW}$ of Glenelg village. BGS Photo P707999. (c) Hinge zone of F3 Beinn Sgritheall Synform, south of Arnisdale village, looking south. BGS Photo P707850. Height of outcrop c. 5 m. (d) Minor F3 folds in thinly banded Western Glenelg gneiss, Rubha Camas na Cailinn. BGS Photo P707465 
F2 fold styles are varied and depend strongly on lithology and finite strain. In thick-bedded psammite and low-medium strain zones as in western Knoydart, F2 folds are open-to-close, nearconcentric folds (Fig. 7a) with poor fabric development and a dominance of intersection over stretching lineations (Krabbendam et al. 2014). In higher strain areas (e.g., in Glen Arnisdale), F2 folds are tight to isoclinal, similar in shape (Fig. 7b), and associated with a strong linear mineral orientation and foldaxis-parallel quartz-feldspar-mica rods.

- D3 folds are recognised by folding or crenulation of all penetrative fabrics (Figs. 7c and d). Only minor recrystallization occurred during D3; new fabric formation, normally a crenulation cleavage, is restricted to hinge zones. D3 structures thus developed at lower metamorphic temperatures than the D2 structures. F3 folds are typically open to close; no tight or isoclinal F3 folds have been observed.

All of these deformation phases affected Morar Group rocks as well as Glenelg gneisses and produced minor fold structures as well as regional-scale folds. This deformation-phase scheme is broadly consistent with that reported in Ramsay (1960, 1963, 2010); Ramsay \& Spring (1962); Tanner (1965, 1971) and Powell (1966, 1974). Differences with other published schemes occur because some studies did not account for the early isoclinal D1 folds (e.g., Ramsay 1958); did not separate the F1 isoclinal infolding of gneiss and psammite from the later F2 folds (e.g., Storey et al. 2004; Storey 2008a) or may not have linked fold generations to specific mineral growth phases (e.g., Barber 2011). We stress that the deformation-phase scheme above only applies to the southern Moine Nappe as discussed here. Deformation phases in the Moine outcrop as a whole cannot a priori be correlated across major thrusts and may only be valid within a particular thrust nappe (Holdsworth et al. 2006; Leslie et al. 2010; Krabbendam et al. 2011; cf. Powell 1974; Tanner 1971; Mendum 2009a; see also discussion in Strachan et al. 2010). Grenvillian and possibly earlier deformation within the Glenelg gneisses prior to Morar Group deposition was significant, but is not considered here; see Storey (2008a) for an analysis of this earlier deformation. The absolute ages of the different deformation phases are discussed later.

\section{Disposition of gneiss units and migmatitic Morar Group}

Western Glenelg gneiss makes up the main Western Glenelg Inlier which comprises two separate strips (WGI-1 and WGI-2), separated by a thin unit of highly deformed Morar Group psammite (Fig. 4). North of Glenelg village this thin psammite strip thins out and a single band of Western Glenelg gneiss continues north to Lochcarron (Fig. 2b), where its northern termination unfortunately occurs below sea level (Barber 2011). Basement gneiss on southern Sleat directly above the Moine Thrust is also Western Glenelg gneiss (Fig, 2b). South-east of the Strathconon Fault, two narrow strips of Western Glenelg 
gneiss occur east of Arnisdale village (Fig. 4 and 8); these are the equivalent to the two WGI-1 and WGI-2 strips NW of the fault (Ramsay 2010a). Smaller inliers of Western Glenelg gneiss occur along the north coast of Loch Hourn west of Arnisdale village; these occur at a similar structural level as a small inlier of Western Glenelg gneiss at Slisneach, in NW Knoydart (Fig. 4).

In SW Knoydart a hook-shaped inlier of Western Glenelg gneiss (Ramsay \& Spring 1962; Krabbendam et al. 2014) forms the northern part of the Morar Window, which continues farther south of Loch Nevis. This latter gneiss inlier is exposed in a series of narrow outcrops that almost surround the Morar Window (Fig. 2b): these gneisses comprise felsic and mafic orthogneiss with mafic sheets only (Lambert \& Poole 1964), suggesting correlation with Western Glenelg gneiss.

Eastern Glenelg gneiss, with its distinct metasedimentary lithologies, makes up the main Eastern Glenelg Inlier. This inlier occurs between the Strathconon Fault and Loch Duich, and continues north to terminate just south of Loch Long (Fig. 2b; Storey 2008a; May et al. 1993; Barber 2011). A thin, partially dismembered sliver of gneiss directly south of Kilillan appears to be continuous with the main Eastern Glenelg Inlier (British Geological Survey 1984). Inliers farther NE are small or poorly surveyed, but crystalline marble is reported in Coire Shlat (Fig. 2b; May et al. 1993), marble and calcsilicate are reported in Coire nan Gall (Fig. 4; May et al. 1993), whereas the An Cruachan gneiss inlier $10 \mathrm{~km}$ farther NW [NH 09 35] is reported to contain graphitic schist and eclogitic rock (Peach et al. 1913), consistent with the Eastern Glenelg gneiss assemblage. A number of 'Lewisianoid' gneiss inliers farther NE (e.g., Scardroy, Strathfarrar and Loch Shin inliers; Fig. 2a) also contain layers of quartzite, calc-silicate gneiss, crystalline marble and/or graphitic schist (Read et al. 1926; Sutton \& Watson 1953; Strachan et al. 2002; Ramsay 2010b), suggesting possible affinity with Eastern Glenelg gneiss.

South of the Strathconon Fault, an arcuate inlier of Eastern Glenelg gneiss with eclogite and forsterite marble occurs near Glen Arnisdale, termed here the Arnisdale Inlier (Figs. 4 and 8). The thin gneiss sliver that surrounds the Saddle Window (Fig. 4) contains forsterite-bearing marble, calc-silicate, pelitic gneiss and rare eclogite (Simony 1973; May et al. 1993) and thus also comprises Eastern Glenelg gneiss. No rocks resembling the Eastern Glenelg gneiss have been found SE of Glen Arnisdale or The Saddle.

Migmatitic Morar Group rocks occur in (i) the Morar Window in the core of the Morar Antiform, (ii) the Saddle-Ratagain Window, (iii) in Glen Arnisdale. In Glen Arnisdale the migmatitic front obliquely cross-cuts oblique well-mapped stratigraphic boundaries of the Morar Group, confirming the migmatitic rocks are indeed Morar group (Kennedy 1955). All occurrences are bound by, or are closely associated with, basement gneiss (Figs. 2b, 4 and 8). 


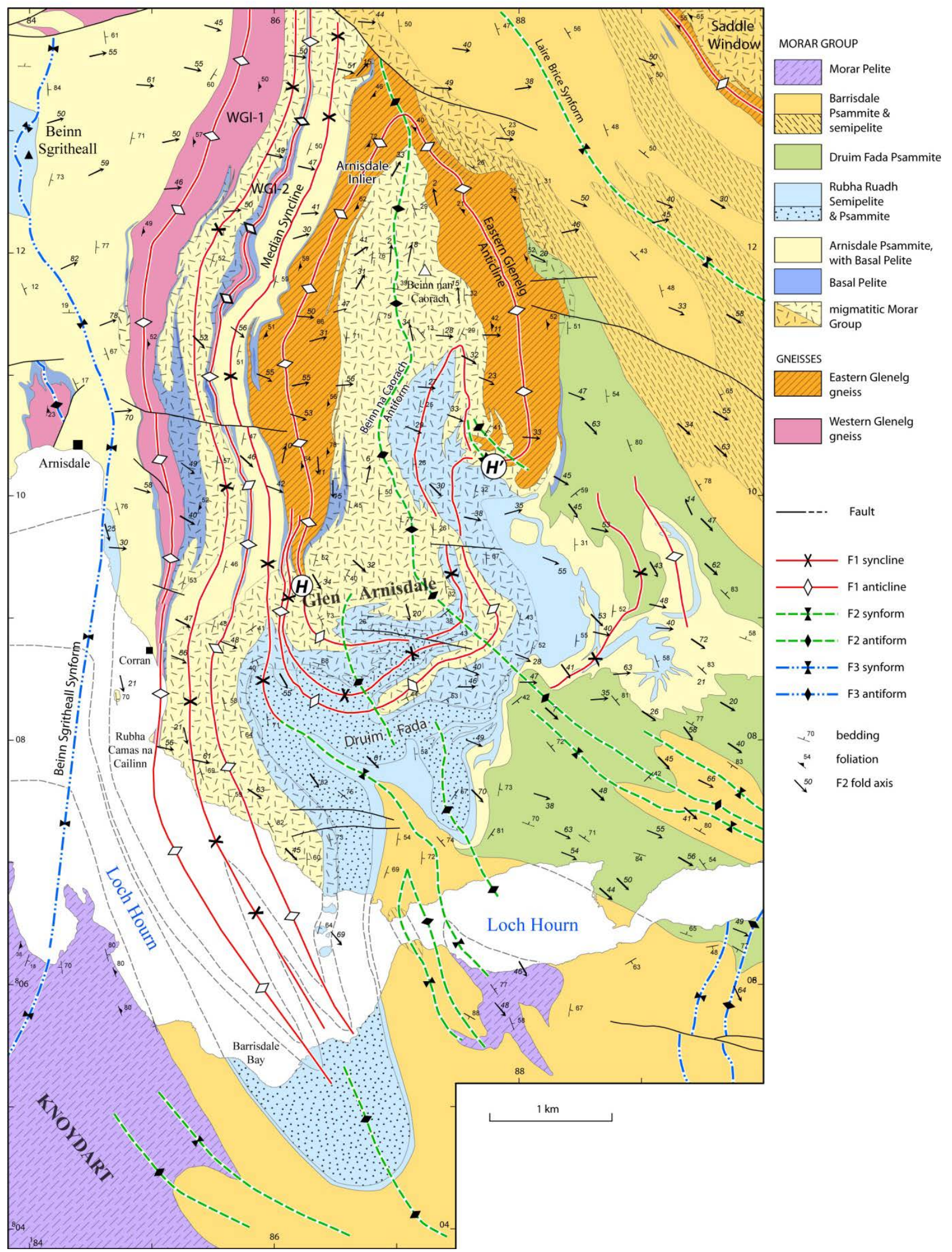

Fig. 8. Detailed geological map of Glen Arnisdale, mapping by PWGT and JGR. Points $\boldsymbol{H}$ and $\boldsymbol{H}$ ' are discussed in text. 


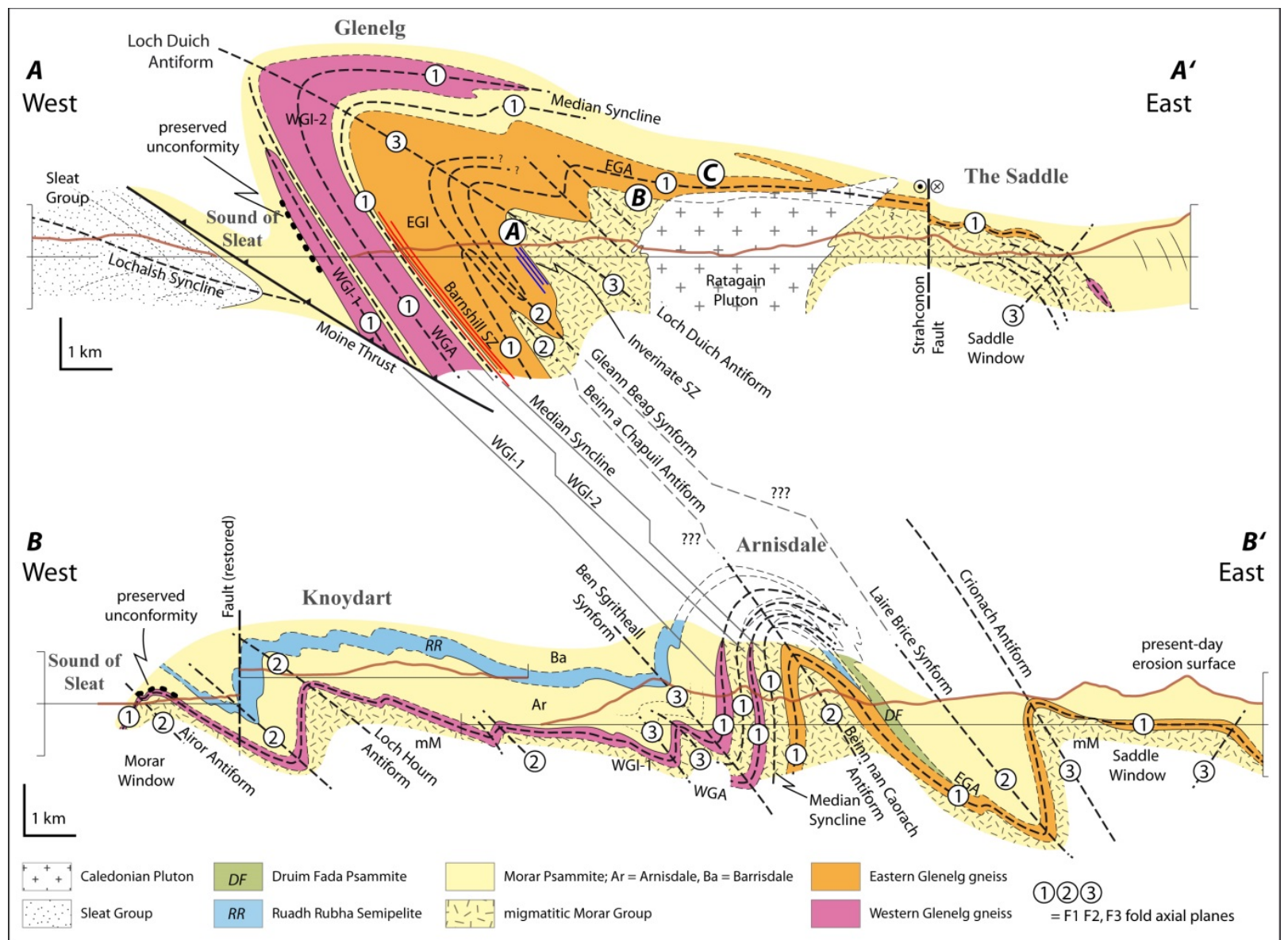

Fig. 9. Schematic cross-section of the Glenelg Inlier north of the Strathconon Fault (A-A') and south of the Strathconon Fault (B-B'). Cross-sections were constructed along two main section lines (A-A' and B-B'), with supporting cross-section (a-a' and b-b') marked on Figure 4, stacked onto each other to portray greater structural depth. Linkages between fold structures are discussed in the text. Note that the axial planes of the Beinn a' Chapuill folds are highly oblique to plane of section. Points $\boldsymbol{A}, \boldsymbol{B}$ and $\boldsymbol{C}$ discussed in text.

\section{Major structures}

The main fold traces are shown on Figure 4 and in cross-sections on Figure 9.

\section{Major F1 folds}

Exceptional exposures of outcrop-scale F1 folds occur at Rubha Camas na Cailinn, on the north shore of Loch Hourn (Fig. 8), where Morar Group psammite and Western Glenelg gneiss (WGI-1) are isoclinally interfolded (Fig. 6a; Ramsay 1963, 2010a; see also description in Mendum et al. 2009a); these folds are demonstrably overprinted by F2 folds, fabrics and lineations. The F1 folds here plunge SSE. South-east of Rubha Camas na Caillin, the Morar Group strip between the Western and Eastern Glenelg gneiss opens out southwards into a clear F1 synclinal structure, the Median Syncline (Fig. 8) and involves stratigraphically higher units of the Morar Group in its hinge zone. These tight to isoclinal F1 synclines 
clearly equate with those responsible for the thin strips of Morar Group alternating with gneiss that occur NW of the Strathconon Fault. Thus, both Western and Eastern Glenelg gneisses occur in the cores of isoclinal F1 anticlines, termed the Western Glenelg Anticline and Eastern Glenelg Anticline, respectively (Figs. 8 and 9).

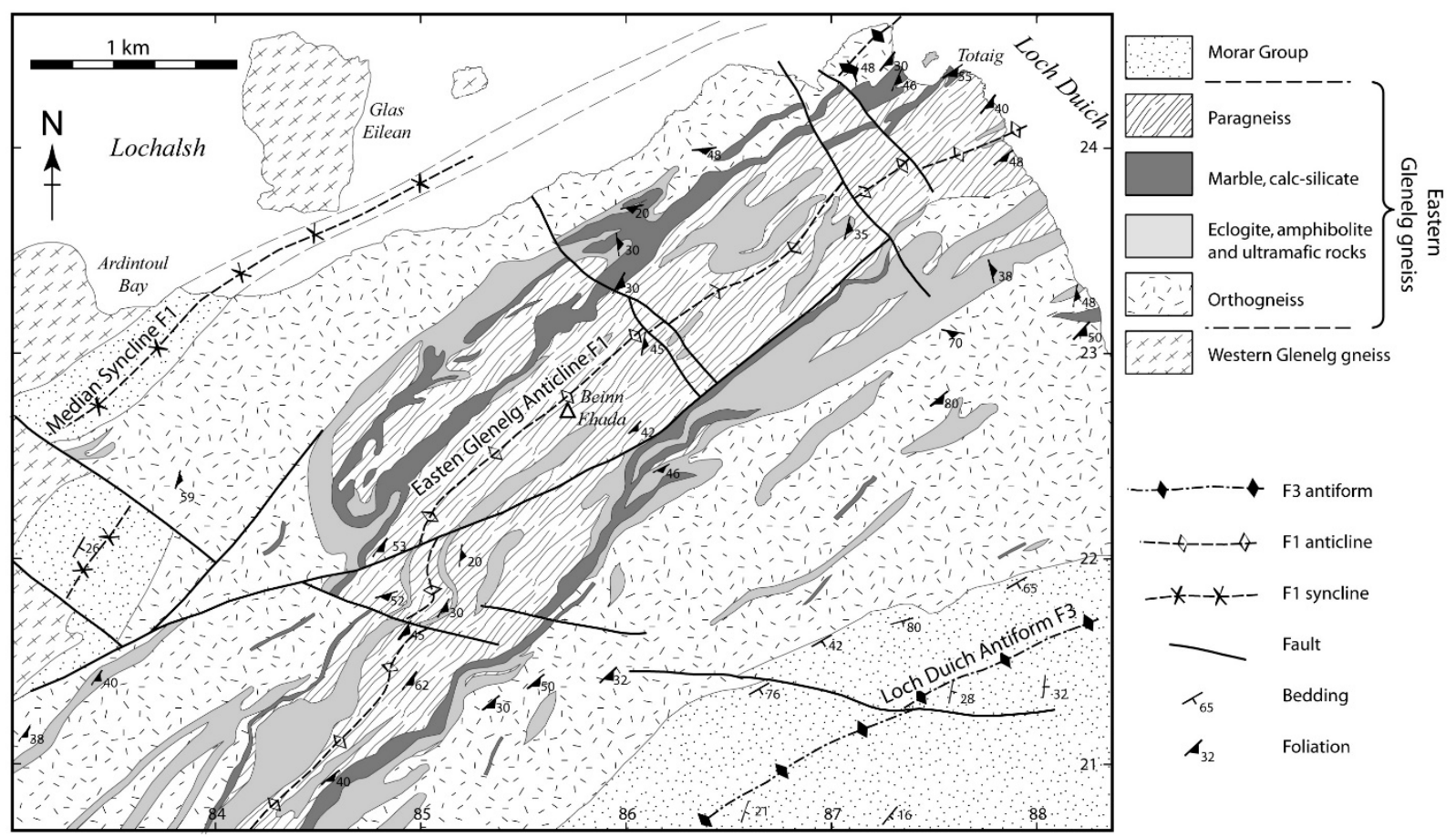

Fig. 10. Detail of northern part of the Eastern Glenelg Inlier, showing subdivision of lithologies within the Eastern Glenelg Inlier. The isoclinal Eastern Glenelg Anticline is interpreted on the basis of symmetry of lithologies; the close Loch Duich Antiform is constrained on the basis of folded fabrics - see text. After Sutton \& Watson (1958); Storey (2008a) and mapping by the authors.

NW of the Strathconon Fault, evidence for large-scale F1 folding is provided by the symmetrical disposition of lithologies in the main Eastern Glenelg Inlier (Fig. 10). SW of Loch Duich this inlier has a core of paragneiss that is flanked on both sides firstly by a near-continuous strip of forsterite marble and calc-silicate rock, then by grey orthogneiss with abundant eclogite layers, and finally by Morar Group psammite. In the far north of the main Western Glenelg Inlier near Attadale (Fig. 2b), Barber (2011) reported isoclinal F1 folds on c. $100 \mathrm{~m}$ scale, folded by recumbent F2 folds with strong axial planar and linear fabric.

Returning to the SE side of the Strathconon Fault, the gneiss inliers that contain Western Glenelg gneiss in western Knoydart and Morar have Morar Group rocks both structurally above and below them. The Slisneach gneiss inlier is demonstrably folded by F2 folds, and the Morar inlier by the F2/F3 Morar Antiform (Krabbendam et al. 2014). This is consistent with these gneiss inliers forming cores of F1 anticlines, although it is possible that some shearing/thrusting may have occurred (e.g., 
Lambert \& Poole 1964; Ramsay \& Spring 1962; Powell 1974).

In summary, all Glenelg gneiss inliers occur in the cores of early F1 anticlines, whereas Morar Group psammite occurs consistently in the cores of F1 synclines (Figs. 8, 9).

\section{Early shear zones}

The western margin of the main Eastern Glenelg Inlier is marked by a zone of ultramylonite, tens of metres wide (Ramsay 1958), originally mapped by Clough (Geological Survey of Scotland 1909) as “extremely attenuated bands” and termed the Barnhill Shear Zone by Storey et al. (2004). Felsic gneisses are reduced to fine-grained and finely laminated quartz-feldspar rocks while hornblendic and garnetiferous rocks are now seen as olive-grey banded ultramylonite. Strong deformation also affected the ‘Median Strip’ of Morar Group psammite between the main Western and Eastern Glenelg inliers (Storey et al. 2004; Storey 2008b) and adjacent parts of the Western Glenelg gneiss, and also affects the Western Glenelg gneiss near Arnisdale; an example is shown in Figure 6c. A similar high-strain zone occurs on the eastern boundary of the Eastern Glenelg Inlier, near Beinn a'Chuirn; the Inverinate Shear Zone of Storey et al. (2004). This shear zone locally comprises mylonitic amphibolite (Fig. 6d), demonstrating that shearing occurred after eclogite decompression. Morar Group psammitic rocks east of the contact here are, however, coarse grained, strongly recrystallized and migmatitic (Fig. 5f). This suggests that migmatisation post-dated shear zone development.

\section{F2 folds; transport direction during D2}

Numerous outcrop- and regional-scale F2 folds occur throughout the area. Large F2 folds can be mapped using fold vergence changes of minor F2 folds, and cleavage vergence between bedding and the S2 fabric (e.g. Bell 1981). However, the intensity of the D2 strain, F2 fold geometry, character of the axial planar foliation, and the orientation of F2 fold axes vary considerably from place to place. To assess the orientation of F2 fold axes with respect to the Caledonian transport direction, we plot first L2 stretching lineation in areas not affected by F3 folding, e.g. from Balmacara and Armadale areas (Fig. 11a, b). The stretching lineations in these areas are oriented WNW-ESE (mean: azimuth $108 \%$ plunge $28^{\circ}$ ), consistent with the regional WNW Caledonian transport direction (c. 290; e.g. McClay \& Coward 1981). We then rotate F2 fold axes on the limbs of F3 folds to the horizontal around average F3 fold axes (Fig. 11b, c, d). It then appears that F2 fold axes in Knoydart, on the flat limb of the Beinn Sgritheall Synform, are at high angles to the regional transport direction (Fig. 11e). Conversely, F2 fold axes in Glen Arnisdale and around Glenelg are oriented sub-parallel to the regional transport direction (Fig. 11f, g). 


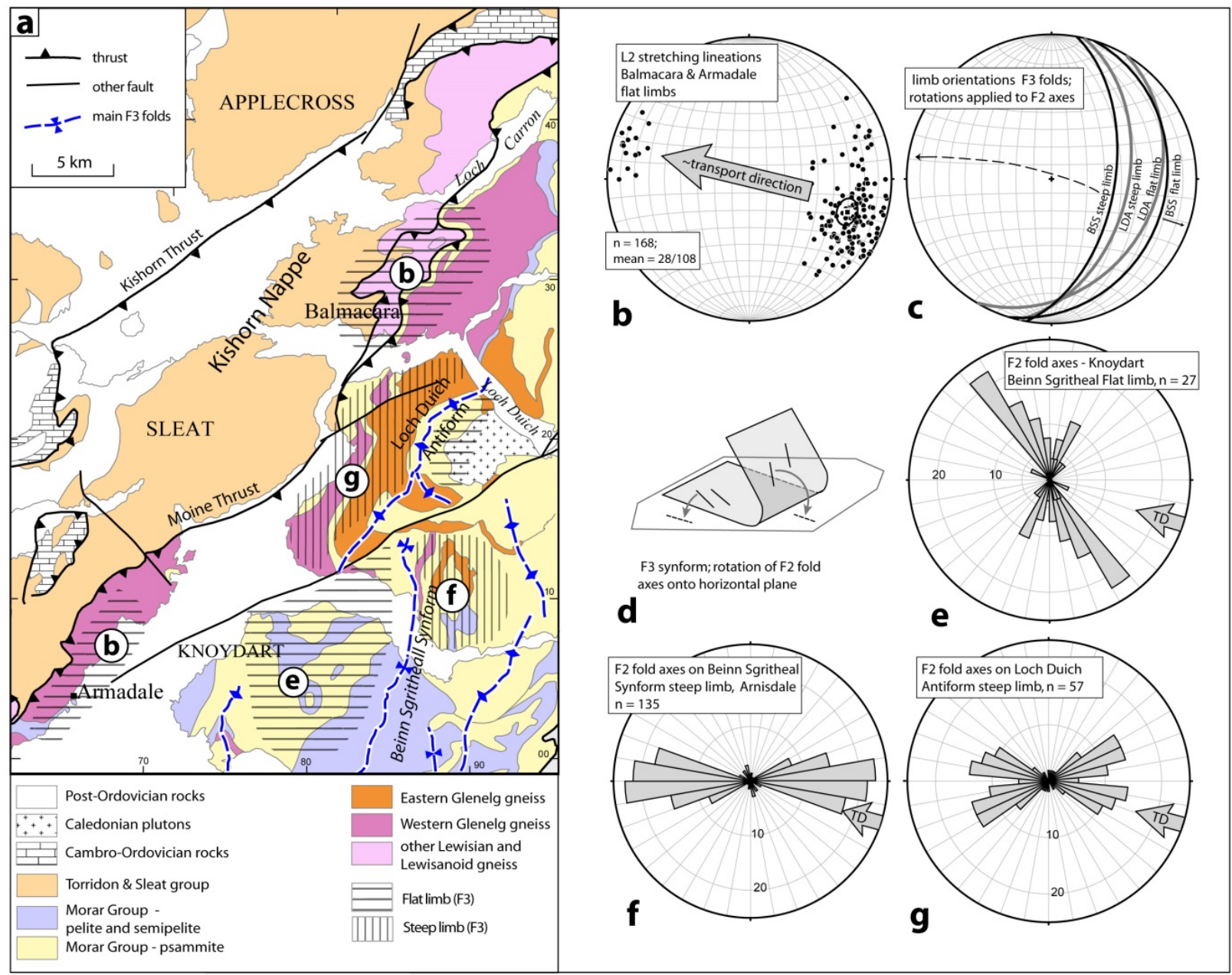

Fig. 11. Orientation analysis of F2 lineations and fold axes

(a) Map showing steep and flat limbs of F3 folds, used to delineate domains for orientation analysis. Circled letters refer to the respective rose diagrams.

(b) L2 stretching lineation from Balmacara and Armadale (Skye), taken as representative for F2 transport direction. Lower hemisphere projection, equal area.

(c) Mean limb orientation of steep and flat limbs of the Beinn Sgritheall Synform (BSS) and the Loch Duich Antiform (LDA), based on bedding/foliation orientation in the limbs. These have been used to re-orientate F2 fold axes onto horizontal plane.

(d) Schematic diagram, showing rotation of F2 fold axes from flat and steep limbs of an F3 synform to the horizontal.

(e) F2 fold axes rotated onto horizontal, from Knoydart on flat limb of Beinn Sgritheall Synform.

(f) F2 fold axes rotated onto horizontal, from Glen Arnsidale within steep limb of Beinn Sgritheall Synform.

(g) F2 fold axes rotated onto horizontal, from Glenelg within steep limb of Loch Duich Antiform.

The Knoydart peninsula is dominated by a series of kilometre-scale west-facing and westvergent F2 folds (Figs. 4 and 9) with north-south trending fold hinges and consistently east-dipping axial planes and fabrics. Named F2 folds include the Loch Hourn and Airor antiforms (Krabbendam et al. 2014). Large areas of Knoydart preserve sedimentary structures, including delicate soft-sediment 
deformation structures (Fig. 5d). L2 lineations are mainly intersection lineations and trend parallel to the main fold axes; L2 stretching lineations are rare (Krabbendam et al. 2014). F2 folds are open to close buckle/flexure folds (Fig. 7a), developed at high angles to the transport direction (Fig. 11e). All these features attest to low-to-medium D2 strain in western Knoydart.

In contrast, in Glen Arnisdale and around Glenelg, D2 strain was intense, with generally tight F2 folds (Fig. 7b) accompanied by well-developed L2 stretching lineations, sub-parallel to F2 fold axes. F2 fold axes and L2 lineations plunge ESE to SE, subparallel to the inferred transport direction (Fig. 11f, g). The F2 folds are interpreted to have rotated towards the transport direction as a result of high D2 shear strain compared to Knoydart. Major, mappable F2 folds include the Beinn nan Caorach Antiform and Laire Brice Synform south of the Strathconon Fault and the Beinn a' Chapuill and Glean Beag folds north of the Strathconon Fault (Ramsay 1960; Tanner 1965). The Beinn a' Chapuill and Glean Beag folds face broadly to the south, where mapped. Such folds are likely to be curvilinear, but individual major folds are not well enough exposed to test this possibility.

\section{Major F3 folds}

The archetypal F3 fold is the Beinn Sgritheall Synform (Ben Sgriol Synform in older publications current Gaelic spelling is followed here) south of the Strathconon Fault, analysed in detail by Ramsay (1960). Its hinge zone is well exposed south of Arnisdale village (Fig. 7c), where all penetrative fabrics are folded around the hinge zone, which itself has only a crenulation cleavage as an axial planar fabric (Ramsay 1960, 2010). The axial plane dips c. $60^{\circ}$ to the east. The fold has a flat to gently east-dipping western limb whereas the eastern limb is subvertical to overturned, steeply east-dipping (Figs. 8 and 9).

Some 8 km farther east, the Crionach Antiform (Tanner 1965, p. 68), forms a large scale, northsouth trending synform-antiform pair with the Beinn Sgritheall Synform. The fold pair has an overall westerly vergence. Both folds plunge gently to the south, so that higher structural levels are exposed farther south (e.g., lower Morar Group, followed by Morar Pelite). Both folds are large-scale structures that can be traced southwards from the Strathconon Fault for 20-30 km or more (Fig. 2b). The steep common limb is some 5-7 km wide and contains the majority of exposed gneiss south of the Strathconon Fault.

North of the Strathconon Fault, the major Loch Duich Antiform, occurs west of the Ratagain Pluton (Figs. 4 and 9). Around its hinge zone, exposed near Letterfearn, the fold axis plunges $10-20^{\circ}$ to the NE. All penetrative fabrics in the Eastern Glenelg gneiss, as well as the main S2 and L2 fabrics in migmatitic Morar psammite, are folded over, and parasitic D3 folds are concentric in style. The Loch Duich Antiform is thus unequivocally an F3 fold (cf. Barber 2011). The antiform has an east-dipping axial plane, with a steep to overturned western limb and a gently dipping eastern limb. In the steep, overturned western limb (A on Figs. 4 and 9), migmatitic Morar Group overlies the Eastern Glenelg 
Inlier (with the contact sheared along the Inverinate Shear Zone), whereas on the gently dipping eastern limb (B on Figs. 4 and 9) the Eastern Glenelg Inlier lies structurally above migmatitic Morar Group (e.g., between Letterfearn and the Ratagain pluton). The F3 Loch Duich Antiform is thus locally a synclinal antiform, facing down to the east (Figs. 4 and 9). This local downward facing confirms that the F3 fold has refolded an earlier, larger-scale fold, most likely the F1 Eastern Glenelg Anticline.

\section{Overprinting relationships}

\section{F1-F2 fold interference: Glen Arnisdale}

Some of the most structurally complex ground in the area occurs in the steep eastern limb of the Beinn Sgritheall Synform in the Glen Arnisdale area (Fig. 8; described in more detail in Tanner, 1965). The effects of the rugged terrain on the outcrop pattern adds to the complexity. Two thin slivers of Western Glenelg Inlier (WGI-1 and WGI-2) and one slice of Eastern Glenelg gneiss occupy the cores of major isoclinal F1 anticlines, separated by F1 isoclinal synclines cored by Morar psammite.
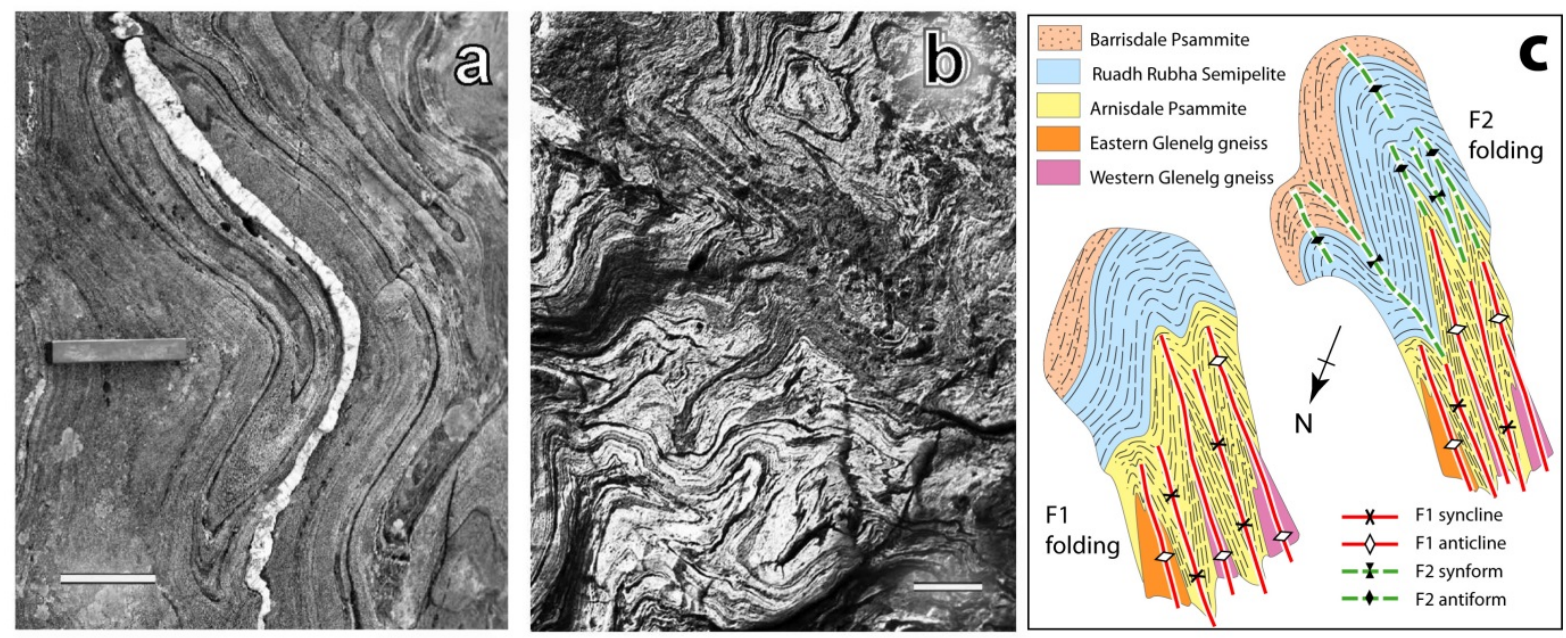

Fig. 12 F1/F2 fold interference. The white scale bar in both photos is $10 \mathrm{~cm}$ long.

(a) F1 isoclinal folds, together with an axial-planar quartz vein, folded by an open F2 fold; F1/F2 axial planes at high angles. Horizontal surface in Coire Mhicrail.

(b) Tight F1 folds folded during D2 and forming a Type 1/Type 3 interference pattern.

(c) Schematic structural map, oriented down-plunge to the SSE, based upon the geology of Arnisdale - Loch Hourne area, showing tightening of F1 folds by F2 folds, resulting in propagation of F2 fold axial planes to higher stratigraphic levels (after Tanner 1965, p. 124).

These structures are overprinted by the large-scale F2 Beinn nan Caorach Antiform (BCA), illustrated on Figs 8, 9, 13a. As a consequence, a great variety of F1/F2 fold interference patterns occur at both outcrop- and map-scale that provide a ready means of distinguishing the two generations of minor folds. Type 3 (co-axial) interference patterns (see Ramsay 1963; 1967, Ramsay \& Huber 1987, p 
492, for definitions of fold interference types) between F1 and F2 are relatively common across the area (Fig. 12a; Tanner 1965, Plates 10, 11); Type 1 (dome-and-basin) occur locally (Tanner 1965, Plates 3, 5, 13, 21) and composite Type 1/3 patterns (Fig. 12b) also occur. Type 2 ('mushroom') forms occur rarely (Tanner 1965, Plate 14, 22; Ramsay 1967) but clearly reflect the geometry of the Arnisdale Inlier as a whole. A quartz-ribbon L1 lineation commonly occurs parallel to the hinges of minor F1 folds, and both elements are deformed into sinusoidal curves on S2, arranged symmetrically about the steeply SEplunging D2 stretching lineation (Ramsay 1960). Most fold patterns are very intricate (Fig. 12a; Tanner 1965, Plate 5, 21) and thus likely to be true fold interference patterns rather than sheath folds, but locally isolated eyed structures occur (e.g. Tanner 1965, Plate 9) which likely formed as single-phase F2 sheath folds, which is compatible with the strongly developed L2 stretching lineations throughout the area.

The large arcuate outcrop of the Arnisdale Inlier resulted from Type 2 refolding of the F1 isoclinal Eastern Glenelg Anticline, with its core of Eastern Glenelg gneiss, by the F2 Beinn nan Caorach Antiform (BCA). The axial plane of the F2 BCA dips moderately east. The fold is periclinal; in the north its fold axis plunges $20-30^{\circ}$ north, whereas in the south it plunges $20-40^{\circ}$ south (Fig. 8). Welldeveloped L2 stretching lineations and sub-parallel F2 fold hinges plunge steeply $\left(40-70^{\circ}\right)$ to the east or SE across the area. An exception to this pattern occurs in the hinge zone of the F2 BCA (Fig. 8), where fold hinges and stretching lineations plunge $\mathrm{N}$ or SE. This deviation may be due to the fact that an early axis-parallel lineation formed in the hinge zone of the BCA and was not subsequently rotated towards the stretching direction, as were the lineations on the limbs of the fold and in the enclosing Morar Group rocks.

Southward from Glen Arnisdale, the F2 BCA changes from a single 'simple' tight structure into a number of individual folds (traceable for a few kilometres at most) in the more distinctly layered Morar Group. The complex outcrop pattern of the Rubha Ruadh Semipelite south of the Arnisdale Inlier are likely the result of F1/ F2 fold interference patterns superimposed upon an equally complex stratigraphy of interbedded and interfingering sandstone and siltstone units. More complex kilometrescale fold interference patterns occur in the area, as described in detail in Tanner (1965).

South of Loch Hourn, F1 axial traces can be followed southward to higher structural and stratigraphic levels, but the same folds change into F2 folds and are seen to refold minor F1 folds (Figs. 8 and 12c; Tanner 1965, p. 125). This suggests (Tanner 1965) that i) F1 folds die out to higher stratigraphic levels, and ii) that subsequent F2 deformation resulted in a tightening of the F1 folds and was accompanied by propagation of folding to higher structural levels, resulting in local co-axial overprinting 
East of the Arnisdale Inlier, the trace of a probable F2 synform, the Laire Brice Synform (Tanner 1965, p. 132), occurs in poorly exposed ground between the Arnisdale Inlier and The Saddle (Figs. 4 and 8). This F2 synform is complementary to the F2 BCA. The axial plane of the F1 Eastern Glenelg Anticline as exposed in Glen Arnisdale likely continues eastward (folded by the Laire Brice Synform) to reappear as the isoclinal anticline that forms the thin arcuate outcrop of Eastern Glenelg gneiss of The Saddle (Fig. 9, and below).

\section{F2/F3 overprinting: Beinn a' Chapuill}

Across much of the Moine Nappe, e.g. in Knoydart and Ross-shire, major F2 and F3 folds trend broadly north-south, F2 axial planes are gently east-dipping and F3 axial planes have a somewhat steeper dip (Powell 1966; Krabbendam et al. 2011; 2014). Overprinting relationships in these cases are either of 'Type 0’ (coaxial and coplanar) or 'Type 3’ (coaxial but non-coplanar).

In contrast, around Beinn a' Chapuill, north of the Strathconon Fault, strongly non-coaxial and non-coplanar F2 and F3 overprinting occurs. Here the NE-SW trending F3 Beinn Mhialairigh Antiform refolds the F2 Beinn a' Chapuill and Glean Beag folds in a 'Type 2' fold interference pattern, described in detail in Ramsay (1958) and shown schematically in Fig. 13b. All major fabrics, fold axes and lineations related to D2 are folded over by the F3 Beinn Mhialairigh Antiform. F2 hinges near the hinge zone at Beinn a' Chapuill plunge steeply to the east as the large scale F2 folds face sideways towards the south. These folds are generally associated with axial plane crenulations and small-scale 'Type 2' interference patterns (Ramsay 1962). Although the major F3 Beinn Mhialairigh fold has a reclined form over much of its trace, it becomes antiformal towards its southeastern limit before it is cut by the Strathconon Fault.

\section{F1/F3 overprinting: The Saddle and Morar Windows}

The area between The Saddle and the Strathconon Fault has not been investigated for this study and our interpretation relies on mapping reported in Simony (1973) and May et al. (1993). The Saddle Window is bounded by a thin sheet of Eastern Glenelg gneiss (Simony 1973; May et al. 1993). The gneiss has an arcuate outcrop (Fig. 4) and structurally overlies migmatitic Morar Group rocks forming the Saddle Window. These latter rocks include mixed migmatitic and gneissose psammitic and pelitic rocks with additional, smaller gneiss slivers in cores of isoclinal folds (Simony 1973; May et al. 1993). The arcuate outcrop shape of the Saddle Window is primarily the result of two major F3 antiforms, trending at right angles to each other in a box-fold type arrangement (Simony 1973). The major north-south trending antiform is the regional-scale F3 Crionach Antiform (Figs. 4 and 8) (Tanner 1965).

Morar Group psammite occurring structurally above The Saddle Window shows relatively low 
strain and locally preserves sedimentary structures (Tanner 1965). The situation is patently similar to that in the Morar Window, and the gneiss sliver in The Saddle area most likely marks the core of a large-scale F1 isoclinal anticline, possibly with a sheared-out lower limb (see also Simony 1973). Thus, The Saddle Window results from an isoclinal F1 fold, refolded by more upright F3 box-folds.

South of The Saddle Window, the hinge and eastern limb of the Crionach Antiform contain a thick but broadly eastward younging sequence of Morar Group psammite, truncated by the Sgurr Beag Thrust farther east (Figs. 2b, 4; Tanner 1965). South of Loch Hourn, the Crionach Antiform is responsible for the large-scale arcuate change in strike of the Morar Pelite. The well-defined base of the Morar Pelite can be reliably correlated over large distances (Tanner 1965) and the psammite of The Saddle area likely equates with the Barrisdale Psammite of Knoydart (Figs. 3, 4). The Crionach Antiform folds three major F2 folds, in ascending order: the Laire Brice Synform, the Beinn nan Caorach Antiform (both described above), and the Sgurr nan Eugallt Synform (Tanner 1965). This latter synform (labelled erroneously as an F3 fold by Powell, 1974) is associated with a penetrative fabric, numerous congruous F2 minor folds, and refolds a single population of isoclinal folds. The synform plunges to the SE and faces sideways to the SW; and as a consequence, Morar Group psammites are inverted in the direct footwall of the Sgurr Beag Thrust south of Kinloch Hourn.

\section{Discussion}

\section{Main folding south of the Strathconon Fault}

The overall structure of the region is discussed first, illustrated by two cross-sections (Fig. 9) and two block diagrams (Fig. 13), to better illustrate the geometric relations in areas of non-coaxial overprinting. The structure of Knoydart is dominated by an internally coherent, right-way-up sequence of Morar Group rocks, several kilometres thick (Figs. 4 and 9; see also Ramsay \& Spring 1962; Krabbendam et al. 2014). This sequence is deformed by large-scale west-facing and west-vergent, broadly co-axial F2 and F3 folds (e.g., Morar and Loch Hourn antiforms) that trend north-south (Krabbendam et al. 2014). This whole package overlies a thin sheet of Western Glenelg gneiss, interpreted as marking the hinge of a regional-scale isoclinal F1 fold. The lower limb of this F1 fold comprises migmatitic Morar Group, exposed in the Morar Window, and most likely underlies most of Knoydart.

Farther east, the Morar sequence is deformed by a regional-scale, west-vergent F3 fold pair (Beinn Sgritheall Synform and Crionach Antiform, Fig. 9). The steep common limb of these F3 folds contains two isoclinal F1 fold cores of Western Glenelg gneiss (WGI-1 and WGI-2) and the Arnisdale Inlier (Eastern Glenelg gneiss). The Western Glenelg gneiss in the F1 fold cores are thought to connect to the Western Glenelg gneiss in the Morar Window, via the small outcrops of Western Glenelg gneiss 


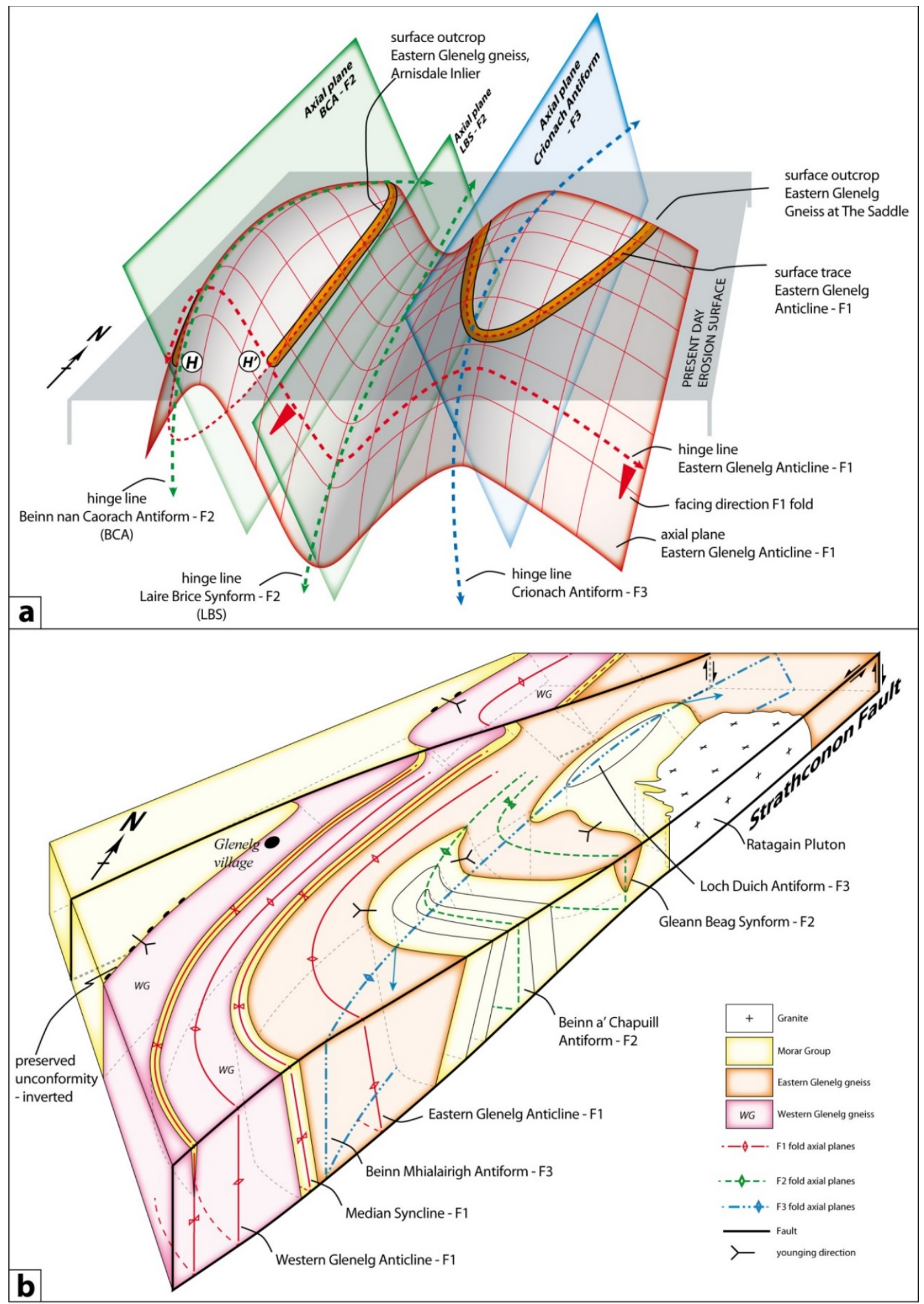

Fig. 13 Schematic block diagrams illustrating the geometry of: (a) F1/F2 overprinting around the Arnisdale Inlier, south of the Strathconon Fault, (b) Schematic block diagrams of F2-F3 overprinting relationships around the Beinn a' Chapuill fold, north of the Strathconon Fault. 
along Loch Hourn and at Slisneach (Fig. 4, 9). Prior to F3 folding, the gneiss-cored F1 isoclines in Glen Arnisdale were positioned structurally below the right-way-up sequence of Knoydart, and the Glen Arnisdale Inlier would be structurally below F1 folds cored by Western Glenelg gneiss (Fig. 9).

Still farther east, the Eastern Glenelg gneiss of the Saddle Window is most likely connected to the Arnisdale Inlier, being folded by the F2 Laire Brice Synform and the F3 Crionach Antiform (Fig. 13a). The Saddle Window is thus analogous to the Morar Window, except in that it contains Eastern Glenelg gneiss in its F1 fold core rather than Western Glenelg gneiss. In both cases, migmatitic Morar Group rocks occur in the lower limb of isoclinal F1 folds and were brought to higher structural levels by F3 antiforms.

\section{Facing direction of F1 folds}

The F1 Eastern Glenelg Anticline in the core of the arcuate Arnisdale Inlier was likely originally recumbent. It was subsequently folded by the periclinal F2 Beinn nan Caorach Antiform, with the F1 fold axis originally at a high angles to theF2 fold axes (Fig. 13a). This resulted in Type 2 (mushroom- or crescent-shape, depending on the erosion level; Ramsay \& Huber 1987, p. 496) fold interference patterns. In the case of the Arnisdale Inlier, a tight crescent is exposed. Despite refolding, the F1 hinge line of a particular horizon (in this case the Eastern Glenelg gneiss / Morar contact) becomes exposed as two hinge points on the surface ( $\boldsymbol{H}$ and $\boldsymbol{H}^{\prime}$ on Fig. 13a). The connecting line between the two hinge points $\boldsymbol{H}$ and $\boldsymbol{H}^{\prime}$ gives an average regional trend for the original $\mathrm{F} 1$ fold axis (Ramsay \& Huber 1987, p. 496). It follows that the regional trend of the F1 Eastern Glenelg Anticline was WSW-ENE. Since older rocks (Eastern Glenelg gneiss) occur north of hinge points $\boldsymbol{H}$ and $\boldsymbol{H}^{\prime}$ and younger rocks to the south, it follows that the facing of the main F1 fold in this area is towards the SSE, very different from the regional westward facing of subsequent F2 and F3 folds. On a regional scale, this broad SSE F1 facing is consistent with the presence of other thin Eastern Glenelg gneiss occurrences to the NNW of this line (e.g., around the Saddle Window), but their absence farther SSE.

\section{Links across the Strathconon Fault}

The Strathconon Fault, which cuts the entire inlier, complicates the interpretation of the earlier ductile folding, as linking all structures across the fault is complex and uncertain. Broadly speaking, the following units and structures can be correlated across the fault (Fig. 9, 14):

(i) the two main inliers of Western Glenelg gneiss WGI-1 and WGI-2,

(ii) the main inliers containing Eastern Glenelg gneiss (Eastern Glenelg Inlier and Arnisdale Inlier);

(iii) the F1 Median Syncline between the main Eastern and Western Glenelg inliers; 
Furthermore, the main F2 folds south of the fault, e.g., Beinn nan Caorach Antiform and Laire Brice Synform are likely equivalent to, and continuous with, the Beinn a' Chapuill and Glen Beag folds north of the fault.

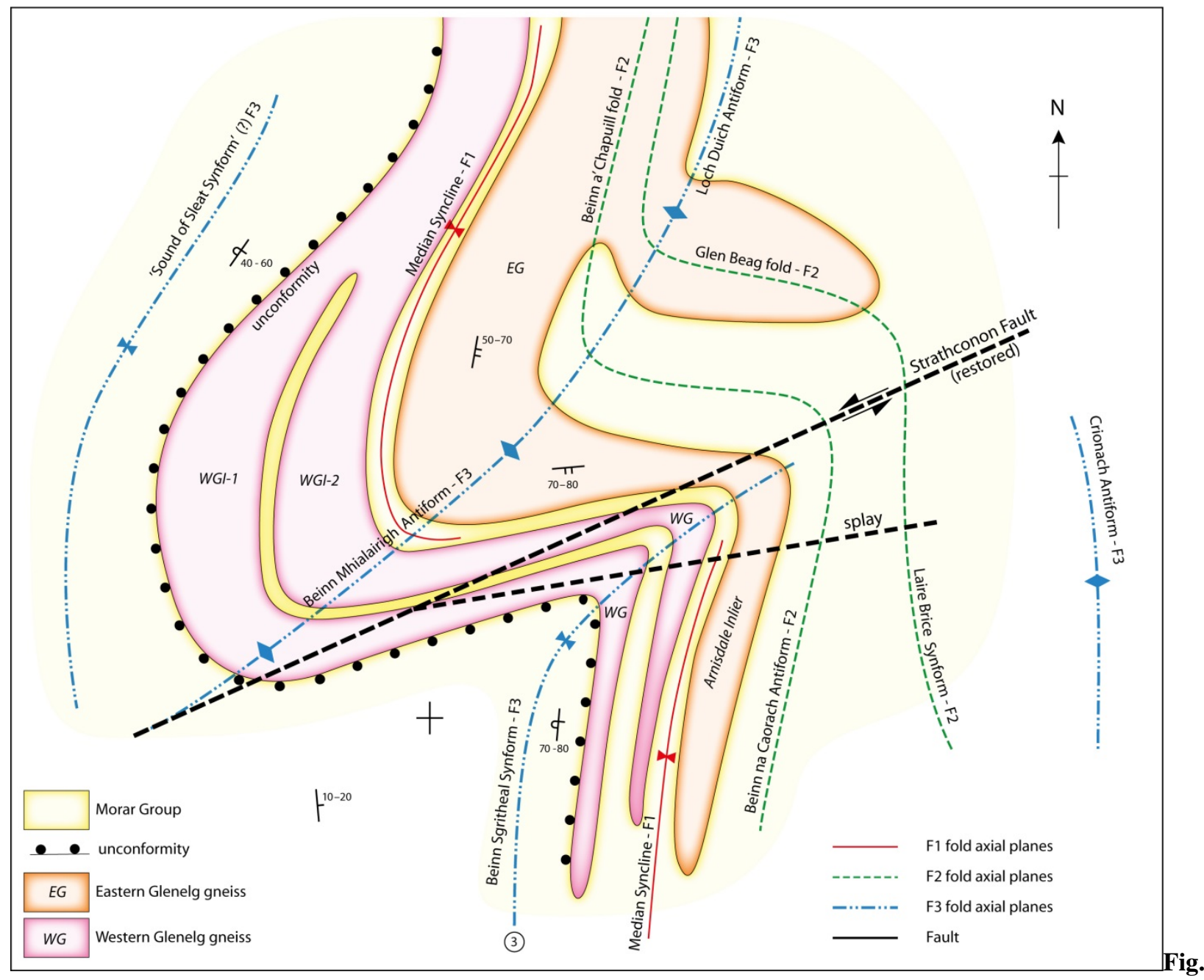

14. Schematic reconstruction prior to movement along the Strathconon Fault; see discussion in text.

These links suggest sinistral movement along the Strathconon Fault: Figure 14 shows a schematic reconstruction, after removing the effects of the Strathconon Fault and its splays. F3 fold links across the fault, however, are more problematic: the Beinn Sgritheall Synform has no obvious counterpart north of the Strathconon Fault, whereas the Beinn Mhialairigh Antiform has no obvious counterpart to the south. It is possible that the F3 Beinn Mhialairigh Antiform is a continuation, or was nucleated upon, the F2 Loch Hourn Antiform on Knoydart (Ramsay \& Spring, 1962). A synform complimentary to the Beinn Mhialairigh Antiform likely occurs in the Sound of Sleat (a putative Sound of Sleat Synform, Fig. 4), which also explains the outcrop of Western Gneiss rocks on Sleat, north of Armadale (Fig. 2). However, the reconstruction of Figure 14 suggests that this synform is not 
continuous with the Beinn Sgritheall Synform. It appears that the F3 folds either side of the Strathconon Fault were arranged in an en echelon fashion, with the steep southern limb of the Beinn Mhialairigh Antiform functioning as an east-west trending linking structure. Unfortunately the termination of the Beinn Mhialairigh to the SW and the Beinn Sgritheall Synform to the NE is not exposed or has been eroded, respectively, so that the exact en echelon arrangement remains uncertain. We note that the en echelon offset arrangement broadly coincides with the change from thick gneiss inliers north of the Strathconon Fault to thin gneiss inliers south of the fault.

Regardless of the manner in which the F3 folds are linked across the Strathconon Fault, the critical constraint is that the widest outcrops of Glenelg gneiss occur in steep overturned limbs of a set of regional-scale west-vergent F3 folds, which certainly include the Loch Duich Antiform and the F3 Beinn Sgritheall Synform (Fig. 8). From here it follows that many field relations involving Glenelg Gneiss (e.g., unconformities, D1 folds and shear zones) were inverted by F3 folding, which is critical to the reconstruction of the earlier evolution of the region.

\section{F3 folding; the original disposition of the F1 folds and position of migmatite}

South of the Strathconon Fault, migmatitic Morar invariably occurs structurally beneath basement gneiss in F1 fold cores. The question is whether this is also the case north of the fault. The F3 Loch Duich Antiform is a key structure north of the Strathconon Fault (Figs. 4 and 9). Most of the outcrop of Glenelg gneiss north of the Strathconon Fault occurs in the steep western limb of this Antiform, so that the original F1/F2 geometry has been overturned. Thus, prior to F3 folding, the unconformable Morar Group-Western Glenelg Inlier contact along the Sound of Sleat was right-way-up. Conversely, before F3 folding, the strongly mylonitic eastern contact (the Inverinate Shear Zone) of the Eastern Glenelg gneiss with the migmatitic Morar Group, was overturned and positioned structurally below the Glenelg Inlier. This latter point may not have been appreciated in previous studies (e.g., Temperley \& Windley 1997; Storey et al. 2004), but is important for the interpretation of this shear zone.

It follows that the flat limbs of the major F3 folds are most representative of the original pre-D3 orientation of D1 structures. The migmatitic Morar Group between the Eastern Glenelg Inlier and the Ratagain Pluton originally occurred in the lower limb of a recumbent F1 fold, just like in Knoydart and in the Saddle Window.

The ground NE of Loch Duich was not examined during this study and it is therefore uncertain how the Loch Duich Antiform may be traced across the loch. Nevertheless, SW of Loch Duich (at $\boldsymbol{B}$ on Figs. 4 and 9) in the eastern flat limb of the Loch Duich Antiform the Eastern Glenelg Inlier-Morar contact is inverted, whereas the same contact NE of Loch Duich ( $\boldsymbol{C}$ on Figs. 4 and 9 ) is right-way-up (Clifford 1957; May et al. 1993; Barber 2011). This suggests i) that these two contacts are at very different 
structural levels and do not represent a single shear zone (cf. Storey 2008a, b) and ii) the likely presence of an early, probable F1 isoclinal fold along Loch Duich and in the volume now occupied by the Ratagain Pluton. This latter putative F1 fold may connect with the F1 fold core of the Saddle Window, although this would be difficult to prove.

Overall, a geometry emerges of a composite, recumbent F1 fold nappe complex with at least three distinct F1 folds: the Western Glenelg Anticline, the Median Syncline and the Eastern Glenelg Anticline (Figs. 4, 8 and 9). The upper limb of this nappe complex comprises Morar Group with a coherent stratigraphy and preserved sedimentary structures, whereas the lower limb, at the structurally deepest levels, is partially migmatitic.

\section{Role of shear zones}

As described above, shear zones occur between the main Western and Eastern Glenelg inliers along the Median Syncline (Barnhill Shear Zone) and to the east of the Eastern Glenelg Inlier (Inverinate Shear Zone) (Figs. 6d, 9). Temperley and Windley (1997) reported top-to-east shear sense indicators in the Inverinate Shear Zone, followed by top-to-the west shearing; Storey et al. (2004) report top-to-the west shear sense indicators in the Barnhill Shear Zone. However, the interpretation of these shear zones is controversial (Temperley \& Windley 1997; Sanders et al. 1997; Storey et al. 2004). Temperley \& Windley (1997) interpreted the top-to-the east shearing as extensional, associated with the collapse of the Grenville orogen and responsible for the exhumation of the eclogite-facies Eastern Glenelg gneisses. However, dating of eclogite exhumation of the Eastern Glenelg Gneiss at c. $995 \pm 8$ Ma (Brewer et al. 2003) and detrital zircon dating of the Morar Group metasedimentary rocks, with the youngest zircons between 1070-1030 Ma (Friend et al. 2003; Kirkland et al. 2008), invalidate this interpretation. Morar Group deposition evidently occurred after exhumation (e.g. Krabbendam et al. 2017) and cannot have formed the direct overburden to the eclogite: the eclogite-bearing Eastern Glenelg gneiss must have been exhumed from beneath an unidentified overburden. Nevertheless, at some time prior to D1-D3 deformation, a major shear zone may well have separated eclogite-bearing Eastern Glenelg gneiss from basement gneisses with lower pressure assemblages. Within the Grenville Province in eastern Canada, shear zones with both thrust and extensional movement, invariably separate high-pressure gneiss units from low-medium pressure gneiss (e.g., Rivers 2008). It is possible that the Barnhill Shear Zone represents the (intensely reworked) remnants of such a late-Grenvillian shear zone, and in effect marks the position of a Grenville (Metamorphic) Front, albeit reworked by postGrenvillian deformation. 


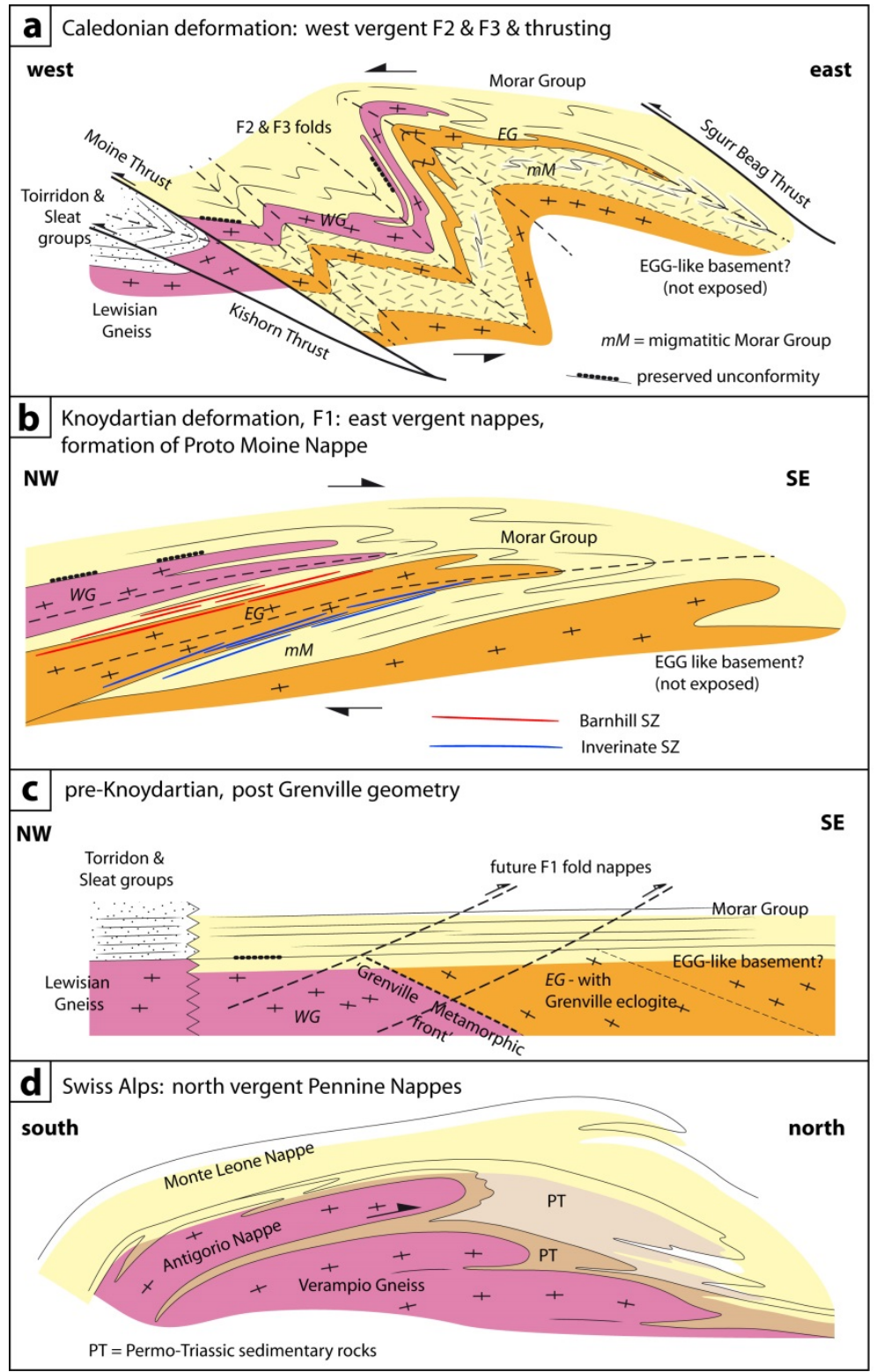

Fig. 15. Schematic structural evolution of the Glenelg Inlier. (a) Schematic cross-section showing west-vergent Caledonian F2 and F3 folding. (b) Cross-section reconstructed prior to F2 and F3 folding: Knoydartian F1 Proto Moine Nappe development. (c) Suggested pre-Knoydartian / post-Grenville geometry. (d) Schematic cross-section across Pennine Nappes, Swiss Alps, after Steck (2008). See text for further discussion.

The early history as outlined above, however, is less likely for the Inverinate Shear Zone, situated farther east and well away from the Western Gneiss Inlier. What is clear is that both shear zones are folded around, and thus predate, the major F2 and F3 folds (Fig. 9). The structural analysis presented here shows that that during D1 folding the Inverinate Shear Zone had gneiss in its hangingwall and migmatitic Morar Group in its footwall (Fig. 15b; cf. Temperley \& Windley 1997; Storey et al. 2004). The parallelism of the shear zones with the traces of F1 isoclinal folds suggest that the shear zones operated as high strain zones along sheared-out limbs during the development of the very attenuated 
isoclinal F1 folds (Fig. 15b); in other words, they are (in part) syn-D1 shear zones. The Barnhill Shear zone may have reactivated an earlier Grenvillian shear zone, whereas the Inverinate Shear zone in the east operated along the Morar Group /Eastern Glenelg contact, in the overturned long limb of an isoclinal F1 fold. The reconstruction in Figure 15b shows a large-scale recumbent nappe complex, cored by gneiss, with more intense shearing at its base than at its top.

\section{A kinematic model for the Proto-Moine Nappe}

The overall model of the evolution of the Glenelg Inlier is proposed as follows (Fig. 15). At some point after Grenvillian orogenesis, a basement partially comprising Grenvillian high-pressure gneisses became covered by siliclastic sediments of the Sleat, Torridon and Morar Group (Fig. 15c) as part of the Grenville foreland basins (see Krabbendam et al. 2017). We surmise that the Eastern Glenelg gneiss with Grenvillian eclogite was structurally positioned over Western Glenelg gneiss and Lewisian Gneiss farther NW, and that more Eastern Glenelg-like gneiss occurred farther NE, but this geometry is very poorly constrained. During F1, presumably during the Knoydartian (see below), a recumbent fold nappe complex developed - termed here the Proto-Moine Nappe. The uppermost limb of the fold nappe comprises a thick slab of relatively low-strain, right-way-up Morar Group with a well preserved stratigraphy, whereas the lower limbs consists of intensely deformed rocks including shear zones. The facing of the fold nappe, as far as the data allow, is towards the SSE, but it is uncertain whether or not this represented the transport direction. However, it appears that the Western Glenelg Gneiss was thrust over Eastern Glenelg gneiss (Fig. 15b), supporting an overall southern or eastern transport direction. Narrow, tight infolds of metasedimentary rocks and gneiss are part of the overall structure, similar to that of the Pennine nappes of the Swiss Alps (Fig. 15d), where thin slivers of Permo-Triassic sedimentary rocks are infolded in between the Antigoria and Verampio basement nappes (e.g., Steck 2008). By analogy with these basement-carrying nappes in the Alps, it is likely that more basement occurs at structurally lower levels (Fig. 15b); but this is not exposed in the Scottish Highlands.

The F1 Proto-Moine Nappe is of significant size: the outcrop and reliable subcrop of the gneiss core and migmatitic lower limb extend over an area of c. 20 x $55 \mathrm{~km}$, stretching from southern Morar to Attadale (Fig. 2b). If the upper limb, comprising right-way-up Morar Group, is coherent across Kintail towards the Fannichs and farther north (which is by no means certain), then the upper limb would include the entire outcrop of Morar Group rocks stretching from Ardnamurchan in the south to the north coast in Sutherland.

The F1 fold nappe was subsequently refolded by F2 and F3 folds (Fig. 15a), presumably during the Caledonian (see below). Peak-metamorphism occurred broadly during F2, with migmatisation occurring consistently at the deepest structural levels. In areas of medium-strain, F2 and F3 folds are 
coaxial and face and verge towards the west; whereas in areas of high D2 strain, F2 fold axes rotated towards parallelism with the WNW transport direction. The F3 anticlinal structures have brought the lower limb of the F1 fold nappe to higher levels.

The Moine Thrust cuts obliquely across F2 and F3 folds (e.g., the Morar Antiform and possibly the Beinn Sgritheall Synform), showing that it formed considerably later than the F1 folds. Thus the development of the Proto-Moine Nappe significantly predates the Moine Thrust, and the Moine Nappe was already a nappe before the Caledonian Moine Thrust developed.

\section{Timing: linking the structural evolution to the geochronological record}

The geochronology of the complex series of tectonic events in the Northern Highlands remains controversial, with a number of unresolved issues (e.g. Oliver 2002; Bird et al. 2013; Dewey et al. 2015; Cawood et al. 2015). The age of Morar Group deposition is constrained by their youngest detrital zircons from the Morar Group (1070-1030 Ma; Friend et al. 2003; Kirkland et al. 2008) and the c. 870 Ma bimodal magmatism affecting the structurally higher and younger Loch Eil and Glenfinnan groups (Friend et al. 1997; Millar 1999; Cawood et al. 2015). Subsequently, the Moine Supergroup was subjected to several orogenic events: Knoydartian, Grampian and Scandian (e.g., Strachan et al. 2010; Cawood et al. 2015).

In the Glenelg/Knoydart area, geochronological ages associated with Knoydartian tectonothermal activity suggest two phases. The first ('Knoydart I') phase occurred around 830-820 Ma, recorded by U-Pb monazite ages on pegmatite and Sm/Nd ages from garnet (Rogers et al. 1998; Vance et al. 1998). The second ('Knoydart II') phase occurred around 790-780 Ma, based on U-Pb monazite and U-Pb zircon ages on pegmatite (Rogers et al. Rogers 1998; Cawood et al. 2015) and garnet Sm/Nd ages from the Ladhar Bheinn pelite (Vance et al. 1998). A third, even later phase of Knoydartian activity around 740-720 Ma has thus far only been recorded in the Sgurr Beag Nappe or in its direct footwall (e.g., Van Breemen et al. 1974; Tanner \& Evans 2003; Cutts et al. 2010).

As to Caledonian activity, the separation between Grampian (c. 470-460 Ma; early Ordovician) and Scandian (440 - 420 Ma; Silurian) affecting the northern Scottish Caledonides has recently been challenged by emerging evidence for late-Ordovician c. 460- 440 Ma activity, suggesting either a distinct ‘Grampian-II' phase or a more protracted, continuous Caledonian orogeny without distinct phases (Bird et al. 2013; Cawood et al. 2015). Garnets from Morar Group pelitic rocks close to the Western Glenelg gneiss have yielded c. 460-450 Ma ages (Lu-Hf and Sm-Nd; Bird et al. 2013); and syn-late D2 pegmatite from Rubha Camas na Cailinn has yielded a U-Pb zircon age of $446 \pm 5 \mathrm{Ma}$ (Cawood et al. 2015). Storey et al. (2004) obtained a U-Pb (titanite) $437 \pm 6$ Ma age from a post-D2 / pre-D3 pegmatite intruding the Eastern Glenelg gneiss. All these ages are from structural levels close to 
or within the Glenelg basement gneisses. Overall we tentatively interpret these dates to indicate that peak-metamorphic D2 in the southern Moine Nappe activity occurred during period 460-440 Ma ('Grampian II'), i.e. later than the 470-460 Ma Grampian activity within the overlying Sgurr Beag and Naver nappes (e.g., Kinny et al. 2003; Bird et al. 2013), but earlier than the 440-420 Ma Scandian deformation that appears to dominate the northern Moine Nappe (Kinny et al. 2003; Alsop et al. 2010; but see Bird et al. 2013). D3 folding, occurring at cooler conditions, is likely to be Scandian and was closely followed by the development of the Moine Thrust Zone in early-mid Silurian (Freeman et al. 1998; Goodenough et al. 2011).

Dates higher up in the structural sequence are rare, but Cawood et al. (2015) report a muscovite c. $460 \mathrm{Ma}{ }^{40} \mathrm{Ar} /{ }^{39} \mathrm{Ar}$ age from the Ladhar Bheinn/ Morar pelite from the synclinal core of the Beinn Sgritheal Synform, interpreted to indicate cooling from a Grampian event, but also suggesting an absence of resetting high up in the structural pile during the 'Grampian II phase'.

With the currently available geochronological data, we propose the west-verging D2 and D3 folds developed during the Caledonian orogeny, with D2 commencing in the Late Ordovician ('Grampian II') and D3 continuing into the Silurian (Scandian). This suggests that the SSE-facing Proto-Moine Nappe developed during the Knoydartian orogeny.

\section{Conclusions}

- Basement inliers in the southern Moine Nappe can be divided into two distinct types: Western Glenelg gneiss, dominated by orthogneiss; and Eastern Glenelg gneiss, containing significant paragneiss and having experienced Grenvillian eclogite-facies metamorphism. The Eastern Glenelg gneiss also occurs in The Saddle Inlier and possibly the An Cruachan Inlier, so extending its known outcrop farther east.

- The Western and Eastern Glenelg gneisses occur in several inliers arranged in the cores of a number of stacked anticlinal F1 isoclines that together form a recumbent D1 fold nappe complex, termed here the Proto-Moine Nappe, a precursor to the Caledonian Moine Nappe Complex.

- The upper limb of the Proto-Moine Nappe comprises a slab $>5 \mathrm{~km}$ thick of medium-strain Morar Group metasedimentary rocks with a coherent stratigraphy.

- By restoring the major F2 and F3 folds it can be shown that strongly deformed, migmatitic Morar Group rocks occur in the lower limb of the F1 fold nappe. Shear zones are interpreted to have resulted from intense shearing along the long limbs of isoclinal F1 folds. These shear zones occur between F1 isoclinal folds and, after F2/F3 restoration, structurally below the F1 
fold-nappe complex. No unequivocal structures related to the Late-Grenvillian exhumation of the Eastern Glenelg gneiss are preserved, although it is possible that some shear zones reactivated pre-existing, late-Grenvillian shear zones.

- Restoration of F1/F2 fold interference patterns show that F1 folds were SSE facing, consistent with the spatial distribution of gneiss inliers of Eastern-Glenelg-gneiss affinity. It is uncertain whether or not this represented the transport direction of the F1 fold nappe.

- Prior to the onset of F2 and F3 folding, the Eastern Glenelg gneiss inliers within the F1 ProtoMoine Nappe complex occurred at structurally lower levels than the inliers of Western Glenelg gneiss. Western Glenelg gneiss bodies were likely thrust over Eastern Glenelg gneiss bodies.

- The core and lower limb of the F1 Proto-Moine Nappe is proven over an area (outcrop and reliable subcrop) of c. 20 x $50 \mathrm{~km}$. If the upper limb is coherent north of Kintail, and stretches farther north, the nappe would cover an area of some 70 x $220 \mathrm{~km}$.

- The F1 Proto-Moine Nappe is refolded by F2 and F3 folds; these are typically west-facing and west-vergent over much of the area. In areas of high F2/F3 strain however, F2 fold axes have been rotated towards a dominant WNW transport direction; in these areas F2/F3 fold interference is non-coaxial.

- The best fit with the available geochronological data suggests that the SSE-facing F1 ProtoMoine Nappe developed during Knoydartian (Mid-Neoproterozoic) orogenesis, whilst the westfacing and west-vergent F2 and F3 folds affecting the Glenelg Inlier are Caledonian in age, with F2 probably developed during Late-Ordovician 'Grampian II' phase and D3 during Silurian Scandian orogenesis. The F1 Proto-Moine Nappe thus developed well before the Scandian Moine Thrust.

- The Moine Nappe is a poly-orogenic feature: it originally formed as the Proto-Moine Nappe during Knoydartian orogenesis and was refolded and transported again during Caledonian orogenesis in a different direction.

\section{Acknowledgements}

John Mendum, who sadly passed away in December 2016, is thanked for discussions and comments on an earlier version of the manuscript. Craig Woodward is thanked for assisting in drafting figures. MK, AGL and KG publish with permission of the Director of British Geological Survey (NERC). 


\section{References}

Alderman, A. R., 1936. Eclogites from the neighbourhood of Glenelg, Inverness-shire. Quarterly Journal of the Geological Society of London, 92, 488-528.

Alsop, G. I., Cheer, D. C., Strachan, R. A., Krabbendam, M., Kinny, P. D., Holdsworth, R. E. \& Leslie, A. G., 2010. Progressive fold and fabric evolution associated with regional strain gradients: a case study from across a Scandian ductile thrust nappe, Scottish Caledonides. In: Law, R., Butler, R. W. H., Holdsworth, R. E., Krabbendam, M. \& Strachan, R. A. (eds). Continental Tectonics and Mountain Building: The Legacy of Peach and Horne. Geological Society. London, Special Publication, 335, 253-272.

Bailey, E. B., 1955. Moine tectonics and metamorphism in Skye. Transactions of the Edinburgh Geological Society, 16, 93-166.

Barber, A. J., 2009. Attadale. In: Mendum, J. R., Barber, A. J., Butler, R. W. H., Flinn, D., Goodenough, K. M., Krabbendam, M., Park, R. G. \& Stewart, A. D. (eds). Lewisian, Torridonian and Moine rocks of Scotland. Geological Conservation Review Series, Joint Nature Conservation Committee, Peterborough, 34, 502-506.

Barber, A., 2011. The structure of the Glenelg-Attadale Lewisianoid Inlier and its relationship to the Moine Thrust Zone. Scottish Journal of Geology, 47, 113-132.

Barber, A. J. \& May, F., 1976. The history of the Western Lewisian in the Glenelg Inlier, Lochalsh, Northern Highlands. Scottish Journal of Geology, 20, 35-50.

Barr, D., Holdsworth, R. E. \& Roberts, A. M., 1986. Caledonian ductile thrusting in a Precambrian metamorphic complex: the Moine of NW Scotland. Bulletin of the Geological Society of America, 97, 754-764.

Bell, A. M., 1981. Vergence: an evaluation. Journal of Structural Geology 3, 197-202.

Bingen, B., Andersson, J., Söderlund, U. \& Möller, C., 2008. The Mesoproterozoic in the Nordic countries. Episodes, 31, 29-34.

Bird, A. F., Thirlwall, M. F., Strachan, R. A. \& Manning, C. J., 2013. Lu-Hf and Sm-Nd dating of metamorphic garnet; evidence for multiple accretion events during the Caledonian Orogeny in Scotland. Journal of the Geological Society of London, 170, 301-317.

Bonsor, H. C. \& Prave, A. R., 2008. The Upper Morar Psammite of the Moine Supergroup, Ardnamurchan Peninsula, Scotland: depositional setting, tectonic implications. Scottish Journal of Geology, 44, 1-12.

Bonsor, H. C., Strachan, R. A., Prave, A. R. \& Krabbendam, M., 2010. Fluvial braidplain to shallow marine transition in the early Neoproterozoic Morar Group, Fannich Mountains, northern Scotland. Precambrian Research, 183, 791-804.

Bonsor, H. C., Strachan, R. A., Prave, A. R. \& Krabbendam, M., 2012. Sedimentology of the early Neoproterozoic Morar Group in northern Scotland: implications for basin models and tectonic setting. Journal of the Geological Society of London, 169, 53-65.

Brewer, T. S., Storey, C. D., Parrish, R. R., Temperley, S. \& Windley, B. F., 2003. Grenvillian age decompression of eclogites in the Glenelg-Attadale Inlier, NW Scotland. Journal of the Geological Society of London, 160, 565-574.

British Geological Survey, 1971. Arisaig, Scotland Sheet 61 Solid Edition. One-inch Series. British Geological Survey, Keyworth, Nottingham.

British Geological Survey, 1984. Kintail, Scotland Sheet 72W Solid Edition. 1:50 000 Series. British Geological Survey, Keyworth, Nottingham.

British Geological Survey, 2007. Bedrock Geology UK North, 1:625 000 scale. British Geological Survey, Keyworth, Nottingham.

Butler, R. W. H., 2010. The role of thrust tectonic models in understanding structural evolution in NW Scotland. In: Law, R., Butler, R. W. H., Holdsworth, R. E., Krabbendam, M. \& Strachan, R. A. (eds). Continental Tectonics and Mountain Building: The Legacy of Peach and Horne. Geological Society. London, Special Publication, 293-320. 
Cawood, P., Nemchin, A. A., Strachan, R., Prave, T. \& Krabbendam, M., 2007. Sedimentary basin and detrital zircon record along East Laurentia and Baltica during assembly and breakup of Rodinia. Journal of the Geological Society of London, 164, 257-275.

Cawood, P. A., Strachan, R. A., Merle, R. E., Millar, I. L., Loewy, S. L., Dalziel, I. W. D., Kinny, P., Jourdan, F., Nemchin, A. A. \& Connelly, J. N., 2015. Neoproterozoic to early Paleozoic extensional and compressional history of East Laurentian margin sequences: The Moine Supergroup, Scottish Caledonides. Geological Society of America Bulletin, 127, 349-371.

Chew, D. M. \& Strachan, R. A., 2014. The Laurentian Caledonides of Scotland and Ireland. Geological Society, London, Special Publications, 390, 45-91.

Clifford, T. N., 1957. The stratigraphy and structure of part of the Kintail district of southern Ross-shire - its relationship to the Northern Highlands. Quarterly Journal of the Geological Society of London, 113, 5792.

Coward, M. P., 1983. The thrust and shear zones of the Moine Thrust Zone of NW Scotland. Journal of the Geological Society of London, 140.

Coward, M. P. \& Potts, G. J., 1985. Fold nappes: examples from the Moine Thrust Zone. In: Gee, D. G. \& Sturt, B. A. (eds). The Caledonide Orogen - Scandinavia and related areas, 1147-1158.

Cutts, K. A., Hand, M., Kelsey, D. E. \& Strachan, R. A., 2009. Orogenic versus extensional settings for regional metamorphism: Knoydartian events in the Moine Supergroup revisited. Journal of the Geological Society, 166, 201-204.

Cutts, K. A., Kinny, P. D., Strachan, R. A., Hand, M., Kelsey, D. E., Emery, M., Friend, C. R. L. \& Leslie, A. G., 2010. Three metamorphic events recorded in a single garnet: Integrated phase modelling, in situ LAICPMS and SIMS geochronology from the Moine Supergroup, NW Scotland. Journal of Metamorphic Geology, 28, 249-267.

Daly, J. S., 1996. Pre-Caledonian history of the Annagh Gneiss Complex North-Western Ireland, and correlation with Laurentia-Baltica. Irish Journal of Earth Sciences, 15, 5-18.

Dewey, J. F., Dalziel, I. W., Reavy, R. J. \& Strachan, R. A., 2015. The Neoproterozoic to Mid-Devonian evolution of Scotland: a review and unresolved issues. Scottish Journal of Geology 51, 5-30.

Elliott, D. \& Johnson, M. R. W., 1980. Structural evolution in the northern part of the Moine thrust belt, NW Scotland. Transactions of the Royal Society of Edinburgh: Earth Sciences, 71, 69-96.

Forster, M. A. \& Lister, G. S., 2008. Tectonic sequence diagrams and the structural evolution of schists and gneisses in multiply deformed terranes. Journal of the Geological Society of London, 165, 923-940.

Freeman, S. R., Butler, R. W. H., Cliff, R. A. \& Rex, D. C., 1998. Direct dating of mylonite evolution; a multidisciplinary geochronological study from the Moine thrust zone, NW Scotland. Journal of the Geological Society of London, 155, 745-758.

Friend, C. R. L., Kinny, P. D., Rogers, G., Strachan, R. A. \& Patterson, B. A., 1997. U-Pb zircon geochronological evidence for Neoproterozoic events in the Glenfinnan Group (Moine Supergroup): the formation of the Ardgour granite gneiss, north-west Scotland. Contributions to Mineralogy and Petrology, 128, 101-113.

Friend, C. R. L., Strachan, R. A., Kinny, P. D. \& Watt, G. R., 2003. Provenance of the Moine Supergroup of NW Scotland; evidence from geochronology of detrital and inherited zircons from (meta)sedimentary rocks, granites and migmatites. Journal of the Geological Society of London, 160, 247-257.

Friend, C. R. L., Strachan, R. A. \& Kinny, P. D., 2008. U-Pb zircon dating of basement inliers within the Moine Supergroup, Scottish Caledonides: implications of Archaean protolith ages. Journal of the Geological Society of London, 165, 807 - 815.

Geological Survey of Scotland, 1909. Glenelg, Scotland, Sheet 71. 1:63 360.

Glendinning, N. R. W., 1988. Sedimentary structures and sequences within a late Proterozoic tidal shelf deposit; the upper Morar Psammite Formation of northwestern Scotland. In: Winchester, J. A. (ed). Later Proterozoic stratigraphy of the Northern Atlantic Regions, Blackie, Glasgow and London, 17-31. 
Goodenough, K. M., Millar, I., Strachan, R. A., Krabbendam, M. \& Evans, J. A., 2011. Timing of regional deformation and development of the Moine Thrust Zone in the Scottish Caledonides: constraints from the U-Pb geochronology of alkaline intrusions. Journal of the Geological Society of London, 168, 99-114.

Holdsworth, R. E., 1989. The geology and structural evolution of a Caledonian fold and ductile thrust zone, Kyle of Tongue region, Sutherland, northern Scotland. Journal of the Geological Society of London 146, 809823.

Strachan, R. A. \& Harris, A. L., 1994. The Moine Supergroup. In: Gibbons, W. \& Harris, A. L. (eds). A Revised Correlation of Precambrian rocks in the British Isles, Geological Society of London Special Report, 22, 23-32.

Holdsworth, R. E., Strachan, R., Alsop, G. I., Grant, C. J. \& Wilson, R. W., 2006. Thrust sequences and the significance of low-angle, out-of-sequence faults in the northernmost Moine Nappe and Moine thrust zone, NW Scotland. Journal of the Geological Society of London 163, 801-814.

Holdsworth, R. E., Alsop, G. I. \& Strachan, R. A., 2007. Tectonic stratigraphy and structural continuity of the northernmost Moine thrust zone and Moine Nappe, Scottish Caledonides. In: Ries, A. C., Butler, R. W. H. \& Graham, R. H. (eds). Deformation of the continental crust; the legacy of Mike Coward. Geological Society Special Publications, 272, 121-142.

Hutton, D. H. W. \& McErlean, M., 1991. Silurian and early Devonian sinistral deformation of the Ratagain granite, Scotland: constraints on the age of Caledonian movements on the Great Glen fault system. Journal of the Geological Society of London, 148, 1-4.

Johnstone, G. S., Smith, D. I. \& Harris, A. L., 1969. The Moinian Assemblage of Scotland. In: Kay, M. (ed). North Atlantic Geology and continental Drift: a Symposium, 159-180.

Kennedy, W. Q., 1955. The tectonics of the Morar Anticline and the problem of north-west Caledonian front. Quarterly Journal of the Geological Society of London, 110, 357-390.

Kinnaird, T. C., Prave, A., Kirkland, C. L., Horstwood, M., Parrish, R. \& Batchelor, R. A., 2007. The late Mesoproterozoic-early Neoproterozoic tectonostratigraphic evolution of NW Scotland: the Torridonian revisited. Journal of the Geological Society of London, 164, 541-551.

Kinny, P. D., Friend, C. R. L., Strachan, R. A., Watt, G. R. \& Burns, I. M., 1999. U-Pb geochronology of regional migmatites in East Sutherland, Scotland; evidence for crustal melting during the Caledonian Orogeny. Journal of the Geological Society of London, 156, 1143-1152.

Kinny, P. D., Strachan, R. A., Friend, C. R. L., Kocks, H., Rogers, G. \& Paterson, B. A., 2003. U-Pb geochronology of deformed metagranites in central Sutherland, Scotland; evidence for widespread late Silurian metamorphism and ductile deformation of the Moine Supergroup during the Caledonian orogeny. Journal of the Geological Society of London, 160, 259-269.

Kirkland, C. L., Strachan, R. A. \& Prave, A. R., 2008. Detrital zircon signature of the Moine Supergroup, Scotland: Contrasts and comparisons with other Neoproterozoic successions within the circum-North Atlantic region Precambrian Research, 163, 332-350

Krabbendam, M. \& Rainbird, R., 2012. Discussion: A unifying model for the Torridon Group (early Neoproterozoic), NW Scotland: Product of post-Grenvillian extensional collapse. Earth-Science Reviews, 111, 82-85.

Krabbendam, M., Prave, A. P. \& Cheer, D., 2008. A fluvial origin for the Neoproterozoic Morar Group, NW Scotland; implications for Torridon - Morar group correlation and the Grenville Orogen Foreland Basin. Journal of the Geological Society of London, 165, 379-394.

Krabbendam, M. \& Leslie, A. G., 2010. Lateral variations and linkages in thrust geometry: the Traligill Transverse Zone, Assynt Culmination, Moine Thrust Belt, NW Scotland. In: Law, R., Butler, R. W. H., Holdsworth, R. E., Krabbendam, M. \& Strachan, R. A. (eds). Continental Tectonics and Mountain Building: The Legacy of Peach and Horne. Geological Society. London, Special Publication, 335, 333-356.

Krabbendam, M., Strachan, R. A., Leslie, A. G., Goodenough, K. M. \& Bonsor, H. C., 2011. The internal structure of the Moine Nappe Complex and the stratigraphy of the Morar Group in the Fannichs-Beinn Dearg area, NW Highlands. Scottish Journal of Geology, 47, 1-20.

mkrab 
Krabbendam, M., Leslie, A. G. \& Goodenough, K. M., 2014. Structure and stratigraphy of the Morar Group in Knoydart, NW Highlands: implications for the history of the Moine Nappe and stratigraphic links between the Moine and Torridonian successions. Scottish Journal of Geology, 50, 125-142.

Krabbendam, M., Bonsor, H., Horstwood, M. \& Rivers, T., 2017. Tracking the evolution of the Grenvillian Foreland Basin: Constraints from sedimentology and detrital zircon and rutile in the Sleat and Torridon groups, Scotland. Precambrian Research,, 295, 67-89.

Lambert, R. S. J., 1958. A metamorphic boundary in the Moine schists of the Morar and Knoydart districts of Inverness-shire (northwest Scotland). Geological Magazine, 95, 177-194.

Lambert, R. S. J. \& Poole, A. B., 1964. The relationship of Moine schists and Lewisian gneisses near Mallaigmore, Inverness-shire. Proceedings of the Geologists Association, 75, 1-14.

Leslie, A. G., Krabbendam, M., Kimbell, G. S. \& Strachan, R. A., 2010. Regional-scale lateral variation and linkage in ductile thrust architecture: the Oykel Transverse Zone, and mullions, in the Moine Nappe, NW Scotland. In: Law, R., Butler, R. W. H., Holdsworth, R. E., Krabbendam, M. \& Strachan, R. A. (eds). Continental Tectonics and Mountain Building: The Legacy of Peach and Horne. Geological Society. London, Special Publication, 335, 357-380.

May, F., Peacock, J. D., Smith, D. I. \& Barber, A. J., 1993. Geology of the Kintail district. Memoir for 1:50 000 Sheet 72W and part of 71E (Scotland), British Geological Survey, Scotland.

McClay, K. R. \& Coward, M. P., 1981. The Moine Thrust Zone: an overview. In: McClay, K. R. \& Price, N. J. (eds). Thrust and Nappe Tectonics. Geological Society Special Publication, London, 9, 241-260.

McKerrow, W. S., Mac Niocaill, C. \& Dewey, J. F., 1991. The Caledonian Orogeny redefined. Journal of the Geological Society of London, 157, 1149-1154.

Mendum, J. R., 2009a. Moine (Central) - Introduction. In: Mendum, J. R., Barber, A. J., Butler, R. W. H., Flinn, D., Goodenough, K. M., Krabbendam, M., Park, R. G. \& Stewart, A. D. (eds). Lewisian, Torridonian and Moine rocks of Scotland. Geological Conservation Review Series, Joint Nature Conservation Committee, Peterborough, 34, 467-485.

Mendum, J. R., 2009b. Moine (South) - Introduction. In: Mendum, J. R., Barber, A. J., Butler, R. W. H., Flinn, D., Goodenough, K. M., Krabbendam, M., Park, R. G. \& Stewart, A. D. (eds). Lewisian, Torridonian and Moine rocks of Scotland. Geological Conservation Review Series, Joint Nature Conservation Committee, Peterborough, 34, 547-569.

Millar, I. L., 1999. Neoproterozoic extensional basic magmatism associated with the West Highland granite gneiss in the Moine Supergroup of NW Scotland. Journal of the Geological Society of London, 156, 1153-1162.

Oliver, G. J. H., 2002. Chronology and terrane assembly, new and old controversies. In: Trewin, N. H. (ed). The Geology of Scotland, The Geological Society, London, 201-211.

Peach, B. N., Horne, J., Gunn, W., Clough, C. T., Hinxman, L. W. \& Teall, J. J. H., 1907. The geological structure of the North-West Highlands of Scotland. Memoir of the Geological Survey of Great Britain.

Peach, B. N., Horne, J., Woodward, H. B., Clough, C. T., Harker, A. \& Wedd, C. B., 1910. The geology of Glenelg, Lochalsh and south-east part of Skye (Explanation of one-inch map 71). Memoirs of the Geological Survey . Scotland, Edinburgh.

Peach, B. N., Horne, J., Hinxman, L. W., Crampton, M. B., Anderson, E. M. \& Carruthers, R. G., 1913. The geology of central Ross-shire (Explanation of sheet 82). Memoir of the Geological Survey of Great Britain, HMSO, Edinburgh.

Poole, A. B. \& Spring, J. S., 1974. Major structures in Morar and Knoydart, NW Scotland. Journal of the Geological Society of London, 130, 43-53.

Powell, D., 1966. The structure of the south-eastern part of the Morar antiform, Inverness-shire. Proceedings of the Geologists' Association., 77, 79-100. 
Powell, D., 1974. Stratigraphy and structure of the western Moine and the problem of Moine orogenesis. Journal of the Geological Society of London, 130, 575-593.

Powell, D., Baird, A. W., Charnley, N. R. \& Jordon, P. J., 1981. The metamorphic environment of the Sgurr Beag Slide, a major crustal displacement zone in Proterozoic, Moine rocks of Scotland. Journal of the Geological Society of London, 138, 661-673.

Rainbird, R. H., Hamilton, M. A. \& Young, G. M., 2001. Detrital zircon geochronology and provenance of the Torridonian, NW Scotland. Journal of the Geological Society of London, 158, 15-27.

Ramsay, J. G., 1958. Moine-Lewisian relations at Glenelg, Inverness-shire. Quarterly Journal of the Geological Society of London, 113, 487-523.

Ramsay, J. G., 1960. The deformation of earlier linear structures in areas of repeated folding. Journal of Geology, 68, 75-93.

Ramsay, J. G., 1962. Interference patterns produced by the superposition of folds of similar type. Journal of Geology, 70, 466-481.

Ramsay, J. G., 1963. Structure and metamorphism of the Moine and Lewisian rocks in the north-western Caledonides. In: Johnson, M. R. W. \& Stewart, F. H. (eds). The British Caledonides, Oliver and Boyd, Edinburgh, 143-175.

Ramsay, J. G., 1967. Folding and fracturing of rocks, McGraw Hill, New York.

Ramsay, J. G., 2010a. West Glenelg and Loch Hourn - Excursion 6. In: Strachan, R., Alsop, G. I., Friend, C. \& Miller, S. (eds). An excursion guide to the Moine Geology of the Northern Highlands of Scotland, Edinburgh Geological Society, Edinburgh, 123-136.

Ramsay, J. G., 2010b. Glen Strathfarrar and Loch Monar - Excursion 8. In: Strachan, R., Alsop, G. I., Friend, C. \& Miller, S. (eds). An excursion guide to the Moine Geology of the Northern Highlands of Scotland, Edinburgh Geological Society, Edinburgh, 153-161.

Ramsay, J. G. \& Huber, M. I., 1987. The Techniques of Modern Structural Geology, Volume 2: Folds and Fractures. Folds and Fractures, 2, Academic Press.

Ramsay, J. G. \& Spring, J., 1962. Moine stratigraphy in the Western Highlands of Scotland. Proceedings of the Geological Association, 73, 295-326.

Rawson, J. R., Carswell, D. A. \& Smallwood, D., 2001. Garnet-bearing olivine-websterite within the eastern Glenelg Lewisian of the Glenelg Inlier, NW Highlands. Scottish Journal of Geology, 37, 27-34.

Read, H. H., Phemister, J., Ross, G., Dinham, C. H. \& Macgegor, M., 1926. The geology of Strath Oykell and Lower Loch Shin (South Sutherlandshire and north Ross-shire) (Explanation of sheet 102). Memoirs of the Geological Survey of Great Britain, HMSO, Edinburgh.

Richey, J. E. \& Kennedy, W. Q., 1939. The Moine and sub-Moine series of Morar, Inverness-shire. Bulletin of the Geological Survey, Great Britain, part II, 26-45.

Rivers, T., 1997. Lithotectonic elements of the Grenville Province; review and tectonic implications. Precambrian Research, 86, 117-154.

Rivers, T., 2008. Assembly and preservation of lower, mid, and upper orogenic crust in the Grenville Province-Implications for the evolution of large hot long-duration orogens. Precambrian Research, 167, 237-259.

Roberts, A. M. \& Harris, A. L., 1983. The Loch Quoich Line—a limit of early Palaeozoic crustal reworking in the Moine of the Northern Highlands of Scotland Journal of the Geological Society of London, 140, 883-892.

Roberts, A. M., Strachan, R. A., Harris, A. L., Barr, D. \& Holdsworth, R. E., 1987. The Sgurr Beag nappe: a reassessment of the stratigraphy and structure of the northern Highland Moine. Bulletin of the Geological Society of America, 98, 497-506.

Rogers, G. \& Dunning, G. R., 1991. Geochronology of appinitic and related granitic magmatism in the W Highlands of Scotland: constraints on the timing of transcurrent fault movement. Journal of the Geological Society of London, 148, 17-27.

Rogers, G., Hyslop, E. K., Strachan, R. A., Paterson, B. A. \& Holdsworth, R. A., 1998. The structural setting and $\mathrm{U}-\mathrm{Pb}$ geochronology of the Knoydartian pegmatites of W Invernesshire: evidence for Neoproterozoic tectonothermal events in the Moine of NW Scotland. Journal of the Geological Society, 155, 685-696.

mkrab 
Sajeev, K., Kawai, T., Omori, S., Windley, B. \& Maruyama, S., 2010. P-T evolution of Glenelg eclogites, NW Scotland: Did they experience ultrahigh-pressure metamorphism? Lithos, 114, 473-489.

Sanders, I. S., 1988. Plagioclase breakdown and regeneration reactions in Grenville kyanite eclogite at Glenelg, NW Scotland. Contributions to Mineralogy and Petrology, 98, 33-39.

Sanders, I. S., 1989. Phase relations and P-T conditions for eclogite-facies rocks at Glenelg, North-west Scotland. In: Daly, J. S., Cliff, R. A. \& Yardley, B. W. D. (eds). Evolution of metamorphic belts, Geological Society Special Publication, 43, 513-517.

Sanders, I. S., van Calsteren, P. W. C. \& Hawkesworth, C. J., 1984. A Grenville Sm-Nd age for the Glenelg eclogite in north-west Scotland. Nature, London, 312, 439-440.

Sanders, I. S., Temperley, S. \& Windley, B. F., 1997. Grenvillian extensional tectonics in Northwest Scotland, Comment and reply. Geology, 25, 1151-1152.

Simony, P. S., 1973. Lewisian sheets within the Moines around 'The Saddle' of North West Scotland. Journal of the Geological Society of London, 129, 191-201.

Steck, A. 2008. Tectonics of the Simplon massif and Lepontine gneiss dome: deformation structures due to collision between the underthrusting European plate and the Adriatic indenter. Swiss Journal of Geosciences, 101, 515-546.

Stewart, A. D., 2002. The later Proterozoic Torridonian rocks of Scotland: their sedimentology, geochemistry and origin. Geological Society Memoir, 24, The Geological Society.

Storey, C. D., 2008a. The Glenelg-Attadale Inlier, NW Scotland, with emphasis on the Precambrian high-pressure metamorphic history and subsequent retrogression: an introduction and review. Scottish Journal of Geology, 44, 1-16.

Storey, C. D., 2008b. A field guide to the Glenelg-Attadale Inlier, NW Scotland, with emphasis on the Precambrian high-pressure metamorphic history and subsequent retrogression Scottish Journal of Geology, 44, 17-34.

Storey, C. D., Brewer, T. S. \& Parrish, R. R., 2004. Late-Proterozoic tectonics in northwest Scotland: one contractional orogeny or several? Precambrian Research, 134, 227-247.

Storey, C. D., Brewer, T. S. \& Temperly, S., 2005. P-T conditions of Grenville-age eclogite facies metamorphism and amphibolite facies retrogression of the Glenelg-Attadale Inlier, NW Scotland. Geological Magazine, 142, 605-615.

Storey, C. D., Brewer, T. S., Anczkiewicz, R., Parrish, R. \& Thirlwall, M. F., 2010. Multiple high-pressure metamorphic events and crustal telescoping in the NW Highlands of Scotland. Journal of the Geological Society, 167, 455 - 468.

Strachan, R. A. \& Holdsworth, R. E., 1988. Basement-cover relationships and structure within the Moine rocks of central and southeast Sutherland. Journal of the Geological Society of London 145, 23-36.

Strachan, R. A., May, F. \& Barr, D., 1988. The Glenfinnan and Loch Eil Divisions of the Moine Assemblage. In: Winchester, J. A. (ed). Later Proterozoic stratigraphy of the Northern Atlantic Regions, Blackie, Glasgow and London, 32-45.

Strachan, R., Smith, M., Harris, A. L. \& Fettes, D. J., 2002. The Northern Highland and Grampian terranes. In: Trewin, N. H. (ed). The Geology of Scotland, The Geological Society, London, 81-147.

Strachan, R. A., Holdsworth, R. E., Krabbendam, M. \& Alsop, G. I., 2010. The Moine Supergroup of NW Scotland: insights into the analysis of polyorogenic supracrustal sequences. In: Law, R., Butler, R. W. H., Holdsworth, R. E., Krabbendam, M. \& Strachan, R. A. (eds). Continental Tectonics and Mountain Building: The Legacy of Peach and Horne. Geological Society. London, Special Publication, 231-252.

Sutton, J. \& Watson, J., 1953. The supposed Lewisian inlier of Scardroy, central Ross-shire and its relations with the surrounding Moine rocks. Quarterly Journal of the Geological Society of London, 108, 99-126.

Sutton, J. \& Watson, J., 1958. Structures in the Caledonides between Loch Duich and Glenelg, North-West Highlands. Quarterly Journal of the Geological Society of London, 114, 231-257.

Tanner, P. W. G., 1965. Structural and metamorphic history of the Kinloch Hourn Area, Inverness-shire. London University, London.

mkrab

Page 40 
Tanner, P. W. G., 1971. The Sgurr Beag Slide - a major tectonic break within the Moine of the Western Highlands of Scotland. Quarterly Journal of the Geological Society of London, 126, 435-463.

Tanner, P. W. G., 1976. Progressive regional metamorphism of thin calcareous bands from the Moinian rocks of NW Scotland. Journal of Petrology, 17, 100-134.

Tanner, P. W. G. \& Evans, J. A., 2003. Late Precambrian U-Pb titanite age for peak regional metamorphism and deformation (Knoydartian Orogeny) in the western Moine, Scotland. Journal of the Geological Society of London., 160, 555-564.

Temperley, S. \& Windley, B. F., 1997. Grenvillian extensional tectonics in Northwest Scotland. Geology, 25, 5356.

Thigpen, J. R., Law, R. D., Lloyd, G. E., Brown, S. J. \& Cook, B., 2010. Deformation temperatures, vorticity of flow and strain symmetry in the Loch Eriboll mylonites, NW Scotland: implications for the kinematic and structural evolution of the northernmost Moine Thrust zone In: Law, R., Butler, R. W. H., Holdsworth, R. E., Krabbendam, M. \& Strachan, R. A. (eds). Continental Tectonics and Mountain Building: The Legacy of Peach and Horne. Geological Society. London, Special Publication, 335, 623-662.

Thigpen, J. R., Law, R. D., Loehn, C., Strachan, R., Tracy, R., Lloyd, G., Roth, B. \& Brown, S. J., 2013. Thermal structure and tectonic evolution of the Scandian orogenic wedge, Scottish Caledonides: integrating geothermometry, deformation temperatures and conceptual kinematic-thermal models. Journal of Metamorphic Geology, 31, 813-842.

Tohver, E., Bettencourt, J., Tosdal, R., Mezger, K., Leite, W. \& Payolla, B., 2004. Terrane transfer during the Grenville orogeny: tracing the Amazonian ancestry of southern Appalachian basement through $\mathrm{Pb}$ and $\mathrm{Nd}$ isotopes. Earth and Planetary Science Letters 228, 161- 176.

Tollo, R., Corriveau, L., McClelland, J. \& Bartholomew, M., 2004. Proterozoic tectonic evolution of the Grenville orogen in North America: An introduction. In: Tollo, R., Corriveau, L., McClelland, J. \& Bartholomew, M. (eds). Proterozoic tectonic evolution of the Grenville orogen in North America Geological Society of America Memoir, 197, 1-18.

Van Breemen, O., Pidgeon, R. T. \& Johnson, M. R. M., 1974. Precambrian and Palaeozoic pegmatites in the Moines of northern Scotland. Journal of the Geological Society of London, 130, 493-507.

Vance, D., Strachan, R. A. \& Jones, K. A., 1998. Extensional versus compressional settings for metamorphism: Garnet chronometry and pressure-temperature-time histories in the Moine Supergroup, northwest Scotland. Geology, 26, 927-930.

Watson, J. V., 1984. The ending of the Caledonian orogeny in Scotland. Journal of the Geological Society of London, 141, 193-214.

Woodcock, N. \& Strachan, R., 2012. Geological History of Britain and Ireland, Blackwell Science, Oxford. $2^{\text {nd }}$ Edition. 